Josephine Moate \& Hanna Posti-Ahokas

\title{
OPISKELIJAN JA OPETTAJAN OPAS MONIPUOLISEEN YLIOPISTO-OPISKELUUN
}

Kasvatustieteiden ja psykologian tiedekunta Creating Space -opetuksen kehittämishanke 


\section{JYU REPORTS 5}

Josephine Moate \& Hanna Posti-Ahokas

\section{OPISKELIJAN JA OPETTAJAN OPAS MONIPUOLISEEN YLIOPISTO-OPISKELUUN}

Kasvatustieteiden ja psykologian tiedekunta Creating Space -opetuksen kehittämishanke

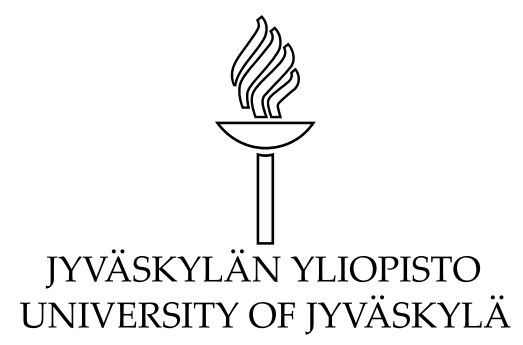

JYVÄSKYLÄ 2021 


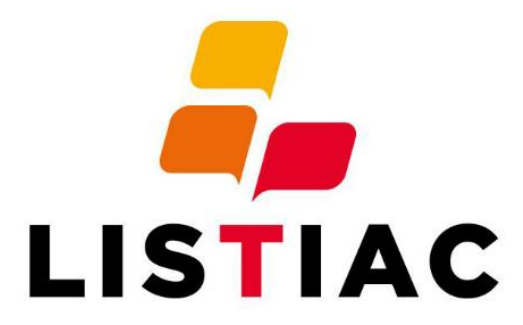

LINGUISTICALLY SENSITIVE TEACHING IN ALL CLASSROOMS

Copyright (c) 2021, by University of Jyväskylä

Permanent link to this publication: http://urn.fi/URN:ISBN: 978-951-39-8820-3

ISBN 978-951-39-8820-3 (PDF)

URN:ISBN: 978-951-39-8820-3

ISSN 2737-0046

DOI 10.17011/jyureports/2021/5

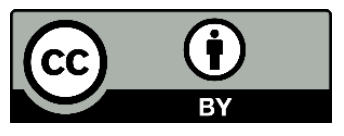

This work is licensed under a Creative Commons Attribution 4.0 International license (CC BY 4.0). 


\section{Sisältö}

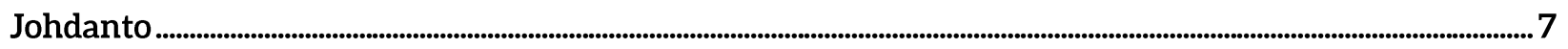

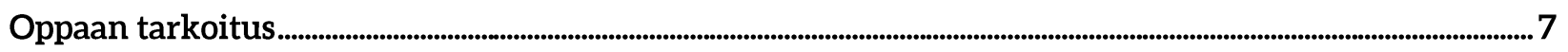

Oppiminen sosiaalisena kokemuksena: tiedon luominen ja yhdessä oppiminen ......................................................... 8

Akateemisten opintojen aloittaminen........................................................................................................................................

Monilukutaito ja multimodaalisuus akateemisessa opiskelussa............................................................................................ 9

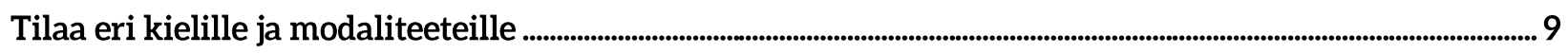

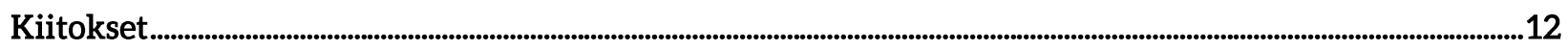

Opiskelun tapoja

Akateemisten lähteiden valitseminen ja niihin viittaaminen

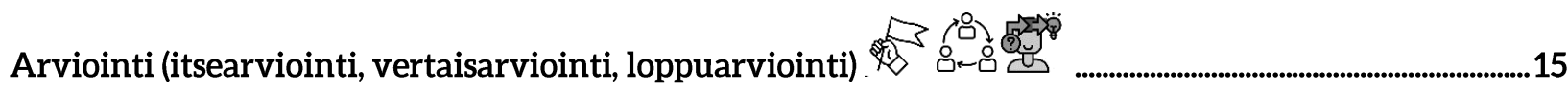

Demot (demonstraatiot)

Digitaaliset oppimisympäristöt ja alustat $\overbrace{0}^{\circ}=0$

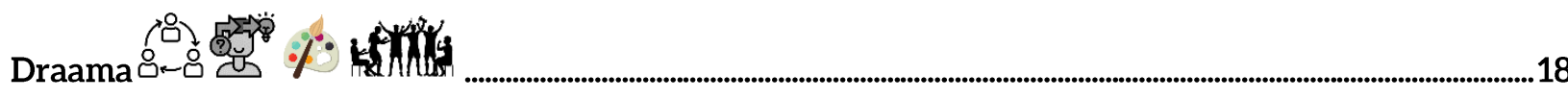

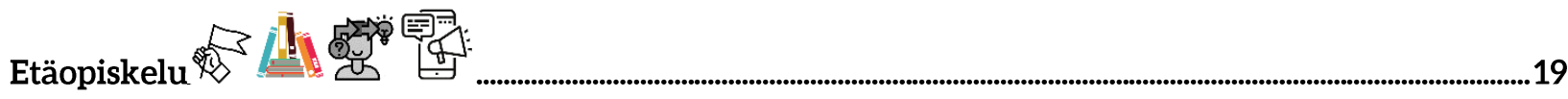

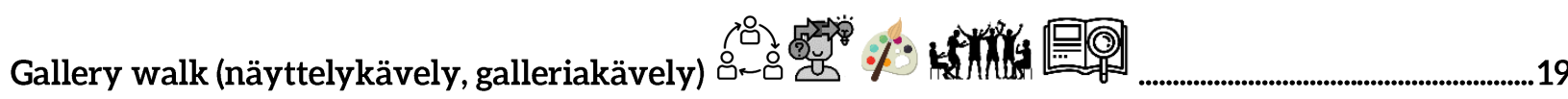

Infografiikat (infogrammit)

Integroivat opiskelumuodot/ opiskelutekniikat

Itsenäinen opiskelu

Itsenäiset oppimistehtävät 


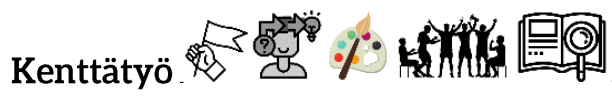

Keskustelukartta tai hiljainen dialogi

Kirjatentti/eTentti

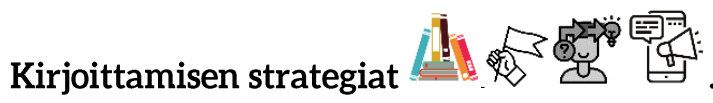

Kirjoitustehtävä/essee

Kommentoitu kirjallisuusluettelo 1 .

Kriittinen ajattelu

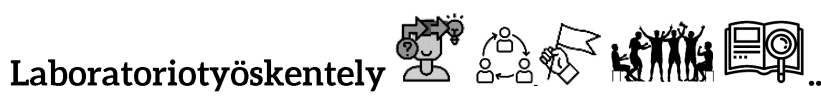

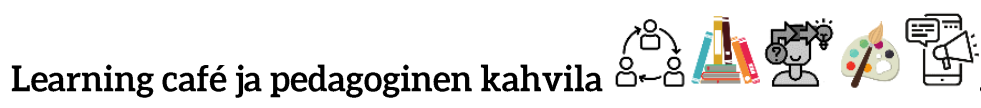

Luennot

Luentopäiväkirja

Lukemistehtävät

Luova kirjoittaminen

Muistiinpanojen tekeminen $\%$

Opetus/Kontaktiopetus

Oppimispäiväkirja Ald

Oppimistehtävät: oppimispäiväkirjat, esseet, lukemistehtävät, ryhmätyöt ......39 
Osallistuminen the

Palaute (vertais- tai ryhmäpalaute)

Posteriesitykset 哭

Projektioppiminen

Reflektiiviset luonnosvihkot (ks. myös osat Reflektio ja Visuaaliset työkalut)

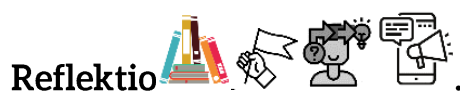

Ryhmätyönä toteutettava esitelmä 哭

Ryhmätyöskentely

Tarinarinki

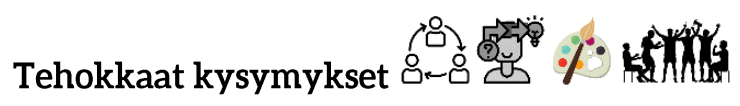

Tentit: yksilö-, ryhmä-, kirjallinen- ja suullinen tenttis

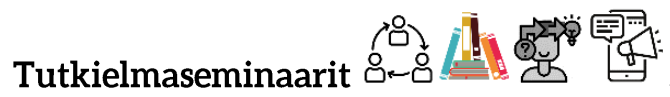

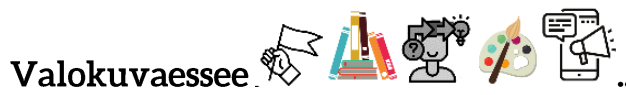

Verkkokeskustelut r̊ำ $_{0}^{\circ}$

Verkkokurssit il

Vertaistuki 吕 


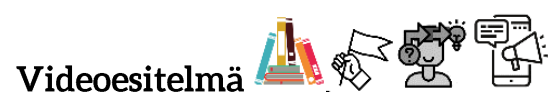

Videoluento 11 㩆

Visuaalinen sadonkorjuu (kuvakiteytys, visualisointi)

Visuaaliset menetelmät ja työkalut

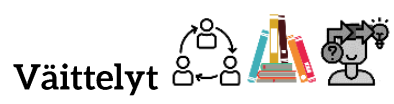

Yksilö- ja ryhmänohjaus

Zine-muotoiset esitykset 


\section{JOHDANTO}

\section{Oppaan tarkoitus}

Oppaan tarkoituksena on tukea monikielisen ja multimodaalisen (monikanavaisen/monimediaisen) opiskelun kehittämistä Jyväskylän yliopistossa. Se on laadittu JY:n kasvatustieteiden ja psykologian tiedekunnassa osana Kieli- ja kulttuuritietoisen oppimisen tilat -hanketta lukuvuoden 2019-2020 aikana, ja siinä on hyödynnetty ja kehitetty edelleen JY:n muita opinto-oppaita ${ }^{1}$. Opas on yleishyödyllinen, koska se lisää kieli- ja kulttuurinäkökulmia aiemmin laadittuihin opinto-oppaisiin. Mukana on kuvauksia erityyppisistä tehtävistä ja aktiviteeteista, jotka kuuluvat korkeakouluopiskeluun ja -opetukseen. Lisäksi opas sisältää hyödyllisiä vinkkejä opiskelijoille ja opettajille, ehdotuksia eri kielten käytöstä apuna opiskelussa ja keinoja, joilla kulttuuritietoisella otteella voidaan edistää akateemista osallisuutta. Puhekuplat ovat lainauksia opiskelijoilta ja opettajilta, jotka ovat osallistuneet Kieli- ja kulttuuritietoisen oppimisen tilat -hankkeen tapahtumiin. Toivomme oppaan lisäävän tietoisuutta eri kielten, kulttuurien ja modaliteettien keskeisestä roolista akateemisissa opinnoissa ja tarjoavan hyödyllisiä pedagogisia työkaluja sekä opiskelijoille että opettajille.

$1 \quad$ Esimerkkejä eri opiskelumuotoja koskevista ohjeista JY:n sivustolla

https://www.jyu.fi/sport/en/study/study-guide/studying/modes-of-study-1 https://www.jyu.fi/hytk/en/studies/studying/modes-of-study https://www.jyu.fi/science/en/study/study-guide/studying/modes-of-study https://www.jyu.fi/it/en/study/study-guide-it/studying/modes-of-study https://www.jyu.fi/edupsy/en/studies/studyguide/study-instructions/modes-of-study https://www.jyu.fi/en/study/new-student-handbook/glossary 


\section{Oppiminen sosiaalisena kokemuksena: tiedon luominen ja yhdessä oppiminen}

Asioita opitaan sekä toisilta ihmisiltä että toisten ihmisten kanssa. Opettajat ja opiskelijat tuovat osaamisensa oppimisympäristöön ja -tilanteeseen. Yhä useammilla opiskelijoilla on kokemuksia eri puolilta maailmaa, ja heidän koulutus- ja kulttuuritaustansa ovat moninaisia ainutlaatuisia. Päämäärämme on saattaa opiskelijoiden osaaminen dialogiin opettajien ja toisten opiskelijoiden osaamisen kanssa ja samalla lisätä ymmärrystä sosiaaliseen, poliittiseen, kulttuuriseen ja taloudelliseen ympäristöön, yhteisöön, koulutukseen ja kommunikaatioon liittyvää moninaisuutta kohtaan. Tarkoituksena on myös kehittää opiskelijoiden valmiuksia työskennellä moninaisissa yhteisöissä ja ympäristöissä soveltaen yliopiston oppimisympäristössä luotuja oppimisprosesseja ja tietoja2.

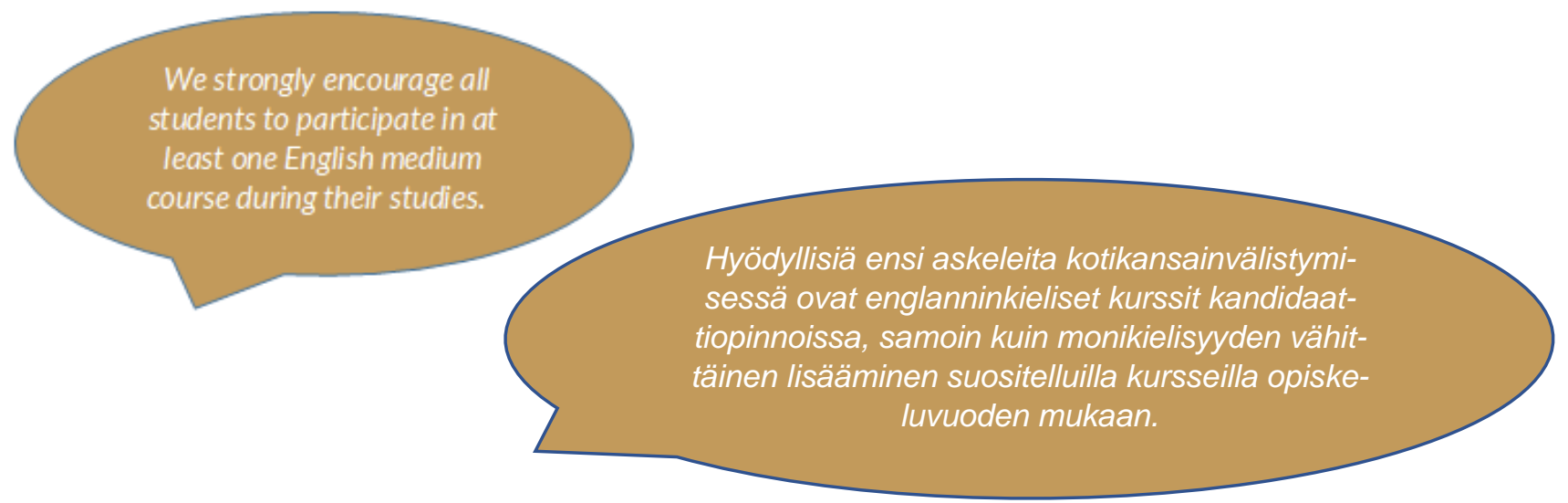

\section{Akateemisten opintojen aloittaminen}

Akateemiset työskentelytavat ovat usein muodollisia ja vaativat hyvää kielitaitoa. Eri kielten ja modaliteettien arvo osana akateemista opiskelua tunnustetaan kuitenkin yhä paremmin. Akateemisia tehtäviä oppii tekemään perusteellisella paneutumisella. Näiden ohjeiden tarkoituksena on selventää, millaisia tehtäviä opintoihin yleensä sisältyy ja kuinka

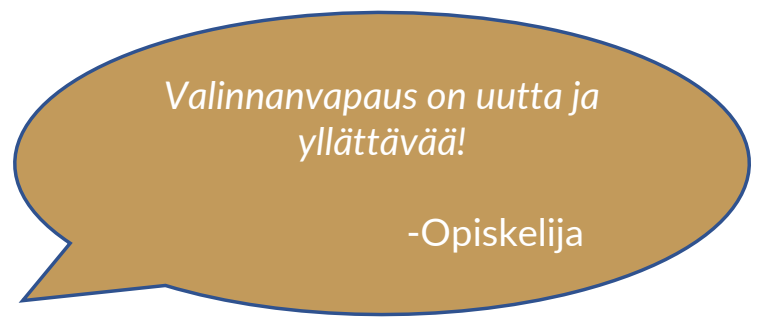


niiden kanssa kannattaa toimia. Opiskeluun kuuluu kuitenkin paljon muutakin kuin tietynlainen muodollinen kielenkäyttö. Opintojen aikana kehittyvät ajattelutaidot, reflektointi ja kyky tarkastella asioita eri näkökulmista. Samoin opitaan arvioimaan ja kommentoimaan toisten työtä, näkökulmia ja tulkintoja. Osaan tässä oppaassa kuvatuista tehtävistä odotetaan luovia, avoimia vastauksia, jotka osaltaan tukevat akateemisen ajattelun kehittymistä. Joissakin tehtävissä taas käytetään tarkoituksella akateemista esitystapaa, mikä auttaa opiskelijaa kehittämään omaa akateemista ilmaisutyyliään.

\section{Monilukutaito ja multimodaalisuus akateemisessa opiskelussa}

Opintoihin kuuluu myös tutustuminen 'keskusteluihin', joita käydään kiinnostuksen kohteena olevista aiheista. Ennen keskusteluun osallistumista on hyvä tietää, mitä on jo sanottu, aivan kuten arkikeskusteluissakin. Oman kontribuution tuottaminen meneillään olevaan keskusteluun on joka tapauksessa tärkeä osa opiskelua. Akateemiseen opiskeluun sisältyvät keskustelut eroavat selvästi arkikeskusteluista, koska niissä esimerkiksi kiinnitetään erityistä huomiota siihen, mitä on jo sanottu ja kuka sen on sanonut. Samoin huomio kiinnittyy tapaan, jolla jotakin sanotaan ja kuinka kyseinen kontribuutio on kehitetty ja julkaistu. Tämä tarkoittaa, että voidaksesi osallistua mielekkäällä tavalla akateemiseen keskusteluun, joudut käyttämään aikaa ja vaivaa keskusteluun perehtymiseen.

\section{Tilaa eri kielille ja modaliteeteille}

Mitä enemmän kieliä ja kulttuureita yksilöllä ja yhteisöllä on kokemusmaailmassaan, sitä enemmän ne tarjoavat resursseja ajattelun ja ymmärryksen kehittämiseen ja tiedon jakamiseen. Jotta useammalle kielelle ja kulttuurille olisi tilaa, pitää kuitenkin miettiä, miksi ja millä tavalla kieliä akateemisissa yhteisöissä käytetään. On tärkeää ja hyödyllistä huomata, että eri kielet tarjoavat erilaisia näkökulmia ja käsitteellistämisen tapoja. Kun yhteisössä huomioidaan erilaisten kulttuuristen painotusten ja prioriteettien olemassaolo, on helpompi tunnistaa vallitsevia olettamuksia, mikä kehittää myös kriittistä ajattelua. Tällaisessa näkemyksessä korostuu

- eri kielillä julkaistun tiedon arvo ja sen huomioiminen, että eri kontekstit perustuvat erilaisiin olosuhteisiin

- eri kielten käyttö oppimis- ja opiskeluprosessin aikana (esim. ajatellaan eri kielillä, mutta käytetään opintojen virallista kieltä tehtävien suunnitteluun ja jäsentämiseen)

- se, että työstä eri kielillä puhuminen ja eri kielten keskeisten käsitteiden avulla ajattelu rikastuttavat ajattelua 
- sellaisten tilanteiden aktiivinen tunnistaminen ja hyödyntäminen, joihin voidaan sisällyttää monikielisiä/multimodaalisia lähestymistapoja.

Edistämme edellä mainittuja seikkoja huomioimalla kielinäkökohdat oppaan sanastossa. Lisää oppimateriaaleja löytyy myös JY:n Monikielisen akateemisen viestinnän keskuksesta (Movi) https://movi.jyu.fi/fi

Huomion kohdistaminen kieleen/kieliin kannustaa pohtimaan eri opiskelumuotoja laajemminkin. Tässä oppaassa käsitellään puhe- ja tekstipohjaista opiskelua sekä visuaalisia, digitaalisia ja kehollisia lähestymistapoja oppimiseen. Vaikka akateeminen maailma on täynnä tiukkoja sääntöjä, opiskelijan kannattaa hyödyntää erilaisia opiskelumuotoja tutkiessaan käsitteitä ja kehittäessään osaamistaan. - Mutta miten eri opiskelumuotoja arvostetaan? Millaisia (usein kätkettyjä) hierarkioita niiden välillä on? Mitä eroja opiskelumuotojen arvostuksessa on eri tieteenalojen välillä? Kielen/kielten ja opiskelumuotojen roolin tarkastelu voi tukea sekä yksin että yhdessä tapahtuvaa pedagogista suunnittelua.

Toivomme tämän oppaan tukevan kurssitehtävien suunnittelua ja monipuolistamista. Opettajan kannattaa pohtia esimerkiksi seuraavia kysymyksiä: Milloin on perusteltua painottaa ja/tai arvioida mieluummin oppimisprosessia kuin oppimisen sisältöä/tuotosta? Kuinka opintojaksoilla voisi tarjota monipuolisia, mielekkäitä oppimiskokemuksia ja opiskelumahdollisuuksia? Opiskelijan kannattaa pohtia esimerkiksi seuraavia kysymyksiä: Mitä oppimistani edistäviä resursseja minulla on? Millaisia opiskelutottumuksia minulle on karttunut opintopolkuni aikana - mitkä niistä ovat hyödyllisiä ja mitä uusia tapoja voisin kehittää? Opiskelijana tavallisesti tietää itse, mitkä opiskeluprosessin osat tuntuvat vaikeimmilta. Haastavaa voi olla esimerkiksi kurssitehtävän aloitus, asioiden tarkastelu eri näkökulmista tai omien käsitysten ja pohdintojen tallentaminen. Toivottavasti tämän oppaan tarjoamat lähestymistavat auttavat osaltaan löytämään uusia antoisia näkökulmia akateemiseen opiskeluun.

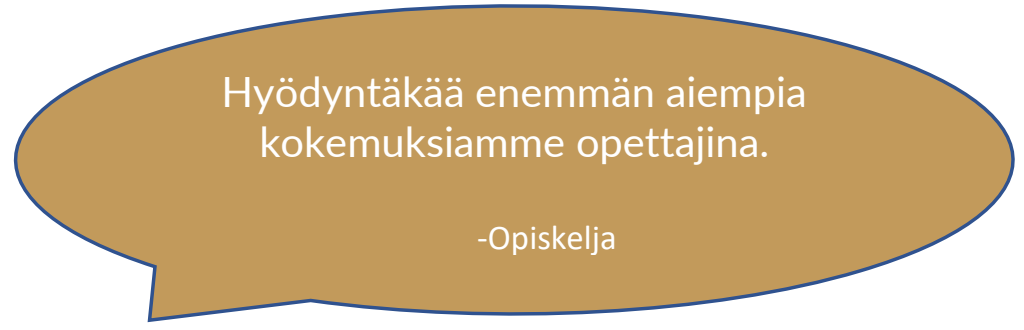

Pedagogiikan ja oppisisältöjen kuvaaminen luo uusia mahdollisuuksia kehittää edelleen kulttuurienvälisyyteen liittyviä hyviä käytänteitä. Koulutusjärjestelmien erilaisista - esimerkiksi taiteiden arvostukseen, digitalisaatioon, kriittiseen ajatteluun ja opetuskieleen liittyvistä - painotuksista tietoisina meidän tulisi kehittää hyvän opiskelun ja työskentelyn 
mahdollistavia välineitä. Opiskelijoiden ja opettajien kokemukset vaikuttavat oleellisesti siihen, kuinka akateemiseen opiskeluun asennoidutaan ja mitä pidetään "akateemisena". Yksilöllisten erojen ja omien olettamusten herkän tunnistamisen tulisi auttaa meitä kouluttajina luomaan kannustavia oppimisympäristöjä, jotka parantavat akateemista viestintää ja lisäävät osallisuutta.

Tämä opas pyrkii herättämään keskustelua siitä, kuinka kielen/kielten ja opiskelumuotojen käyttöä kulttuurienvälisissä oppimisympäristöissä voidaan monipuolistaa. Kulttuurienvälisyys on osa kaikkea inhimillistä vuorovaikutusta. Kulttuurienvälinen lähestymistapa tunnustaa yksilöllisten identiteettien ja oppimisen kulttuuriset samankaltaisuudet ja erot. Kulttuurienvälisessä kompetenssissa on keskeistä erilaisten, muuttuvien identiteettien hyväksyminen ja huomioiminen. Kulttuurienvälisessä pedagogiikassa kiinnitetään huomiota yksilöllisten erojen tarjoamaan mahdollisuuteen avata uusia näkökulmia ja siten rikastuttaa oppimiskokemuksia ja -tuloksia. Pedagoginen kulttuurienvälinen kompetenssi puolestaan auttaa unohtamaan piintyneet ennakkokäsitykset ja essentialismin antaen tilaa kulttuurisesti responsiiviselle toiminnalle.

Oppaan lyhyet kuvaukset ja vinkit sekä 'kieleen ja kulttuuriin liittyvät huomiot' on pyritty tekemään helposti navigoitaviksi. Niiden tarkoituksena on myös innostaa lukijaa jatkamaan omaehtoisen ja yhteisöllisen opiskelun kehittämistä. Toivomme tiiviin oppaan tarjoavan käytännön ohjeita akateemisen opiskelun sisällön ja sitä koskevien käsitysten avartamiseen ja rikastuttamiseen. Kunkin opiskelumuodon nimen yhteydessä olevat symbolit viittaavat modaliteetin tavoitteeseen, eli tukeeko se esimerkiksi akateemisia tekstitaitoja vai tiimityötaitoja.

Josephine Moate, Hanna Posti-Ahokas ja Creating Space / Kieli- ja kulttuuritietoisen oppimisen tilat -työryhmä 


\section{KIITOKSET}

Tämä opas on monivaiheisen yhteistyön tulos. Opas tehtiin pääosin Jyväskylän yliopiston rahoittaman Creating Space -opetuksenkehittämishankkeen puitteissa. Alkuvaiheessa maisteriharjoittelijat Marianne Jaakkola and Viktoria Edes kokosivat olemassa olevia opiskelijoiden ohjeita. Kokemuksemme erityisesti kansainvälisten opiskelijoiden opetuksesta ja ohjaamisesta innosti kieli- ja kulttuuritietoisen opiskelun tarkempaan pohdintaan kunkin esitellyn opiskelutavan kohdalla. Kiitämme opiskelijoita kysymyksistä, avoimesta ihmettelystä ja ehdotuksista! Myöhemmässä vaiheessa saimme uusia näkökulmia tohtoriopiskelija Bhavani Ramamoorthilta, joka sisällytti oppaaseen erityisen luovia, visuaalisia ja kerronnallisia työtapoja sekä loi pohjan oppaassa käytetyille kuvasymboleille. Kiitämme oman asiantuntemuksensa oppaaseen tuoneita kollegoita; Panu Forsman, Anna-Leena Kähkönen, Anssi Lindell, Anne Martin, ja Selma Närkki. Kielen kääntämisessä ja tarkastuksessa ovat auttaneet Sirpa Vehviläinen, Emma Pesu, Hanna Korhonen ja Vesa Moate.

Lämmin kiitos koko työryhmälle!

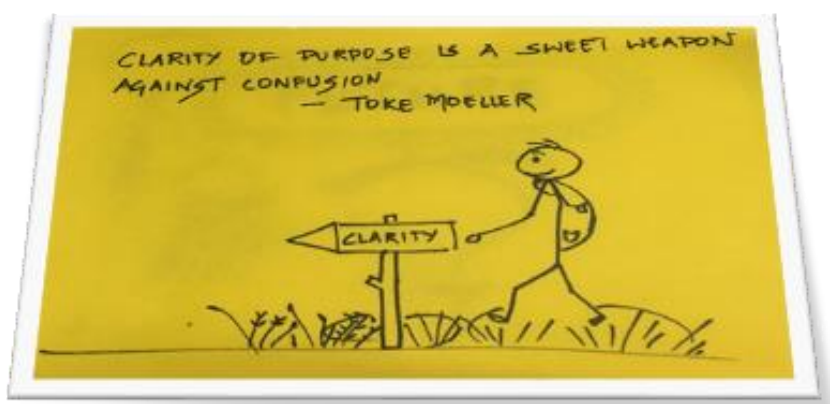

Kuva 1. Clarity of purpose. CBhavani Ramamoorthi 
Taulukko 1. Avainsymbolit

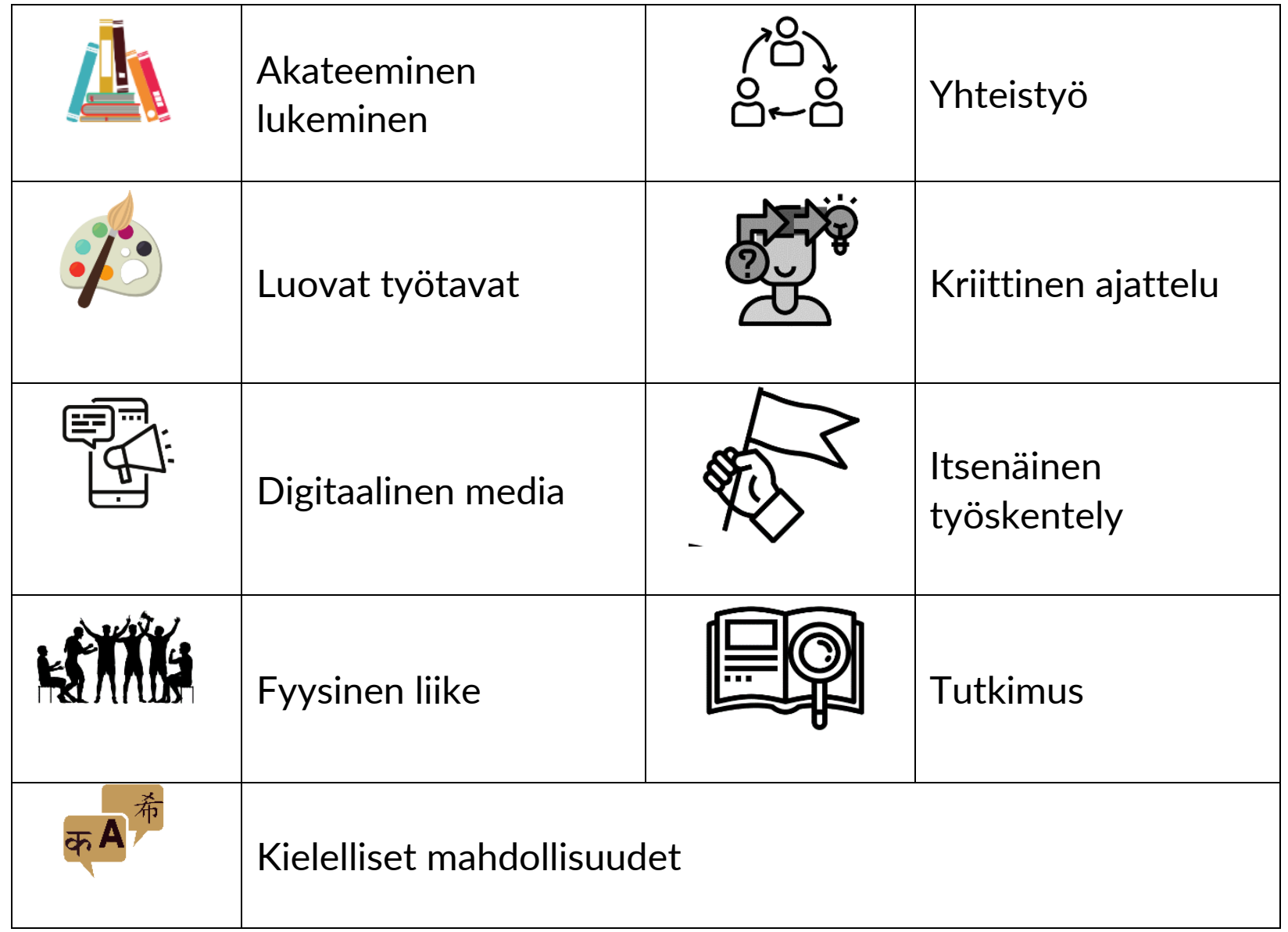




\section{OPISKELUN TAPOJA}

\section{Akateemisten lähteiden valitseminen ja niihin viittaaminen

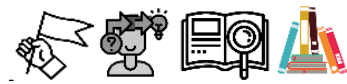

Akateemisen kirjoittamisen perusta on luotettavien lähteiden käyttö. Lähteiden valinta ja laajuus osoittavat aiheen tuntemusta ja lisäävät esitetyn näkökulman ja argumentin luotettavuutta. On tärkeää arvioida tiedon lähteitä kriittisesti, jotta niitä voidaan hyödyntää ja niihin voidaan viitata asianmukaisella tavalla. The Online Writing Lab (OWL) on koonnut hyvät ohjeet lähdeviittauksien ja lähdeluettelon laatimiseen: https://owl.purdue.edu/owl/research_and_citation/using_research/documents/20191212CitationChart.pdf ja https://apastyle.apa.org/

\section{Vinkkejä opiskelijalle:}

- Akateemisen tiedon lähteinä voi käyttää esimerkiksi kirjoja, artikkeleja, tietokantoja ja tietosanakirjoja.

- Omassa tutkimuksessa kannattaa hyödyntää monenlaisia lähteitä, jotta saa kokoon mahdollisimman kokonaisvaltaisen ja ajankohtaisen tiedon, joka voidaan todentaa useasta lähteestä.

- Akateemisen lähteen tarkoituksen, relevanssin, virheettömyyden ja kirjoittajan arviointi on tärkeää, esim. onko kirjoittaja pätevä kirjoittamaan aiheesta, missä tieto on julkaistu ja onko julkaisu vertaisarvioitu.

\section{Vinkkejä opettajalle:}

- Opiskelijat tarvitsevat useimmiten selkeän opastuksen, miten akateemisia/tieteellisiä lähteitä käytetään oikein.

- Opiskelijat on hyvä ohjata kirjaston järjestämille kursseille, joissa neuvotaan miten ja mistä akateemista tietoa etsitään. 
- Akateeminen lähdeviittaustekniikka on oleellinen osa lähteiden valintaa ja käyttämistä. Opiskelijat hyötyvät siitä, että viittausten tekemistä ja lähdeluettelon laatimista harjoitellaan.

\section{Kieleen ja kulttuuriin liittyviä huomioita:}

Google Scholar ja monet muut kirjastojen tietokannat tarjoavat mahdollisuuden

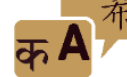
joustavalle tiedonhaulle, ja ne voivat helpottaa erikielisten akateemisten lähteiden löytämistä. Kun opiskelijat ymmärtävät, miten erilaisia lähteitä tulee arvioida, mahdollistaa se tiedon hakemisen eri kielillä ja myös opettajalle tuntemattomien lähteiden hyödyntämisen.

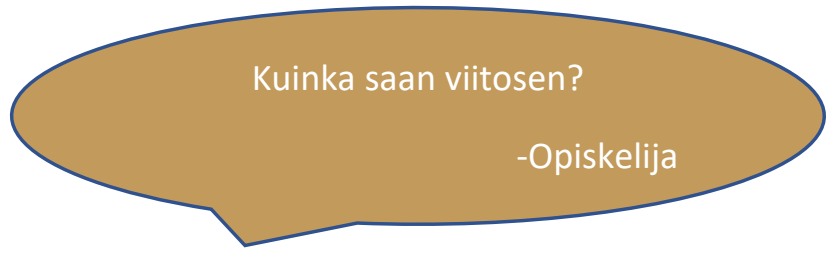

\section{Arviointi (itsearviointi, vertaisarviointi, loppuarviointi) 造拼}

Arviointia voi tapahtua monissa eri muodoissa ja oppimisprosessin eri vaiheissa. Arviointikriteerien tulisi aina vastata oppimistehtävän tyyliä (esim. essee, oppimispäiväkirja) sekä arviointivaihetta (prosessin aikana, prosessin päätteeksi). Kurssin loppuarviointi perustuu usein kokoavaan arvioon, ja se voi sisältää itse- ja vertaisarviointia sekä opettajan tekemää arviointia. Arviointikriteerien tulisi olla näkyvillä opetussuunnitelmassa jokaisen kurssin kohdalla erikseen, ja yksityiskohtaisemmat arviointikriteerit tulee käydä läpi aina kurssin alussa. Arvioinnin tulisi auttaa opiskelijoita tunnistamaan omaa oppimistaan ja kehitystään, mutta myös kehittämiskohteita jatkoa varten.

\section{Vinkkejä opiskelijalle:}

- Selkeät kriteerit ovat arvioinnin perusta. Tehdessäsi vertais- tai itsearviointia muista kiinnittää huomiota sekä myönteisiin asioihin että kehityskohteisiin.

- Tutustu huolellisesti eri arvosanojen kriteereihin. Kun arvioit omaa työtäsi, muista olla rehellinen mutta myös armollinen. Arvosanalle 3 tai enemmän täytyy löytyä selkeät perusteet, oli kyse sitten itsearvioinnista tai vertaisarvioinnista.

\section{Vinkkejä opettajalle:}

- Kaikille arvosanoille täytyy löytyä selkeät perusteet, erityisesti alle kolmosen arvosanoille. Palautetta kannattaa antaa aina, olipa se muodoltaan kirjoitettua tai suullista. 
Myös mahdollisuus palautteen saamiseen kannattaa tehdä opiskelijoille selväksi jokaisen kurssin yhteydessä.

- Mikäli kurssi sisältää vertaisarviointia, on siihen hyvä antaa selkeät ohjeet ja kriteerit. Näin jokainen varmasti ymmärtää tehtävän merkityksen myös oman oppimisensa kannalta.

- On tärkeää antaa tilaa ja aikaa vertaisarvioinnin aiheuttamalle keskustelulle - myös mahdollisille erimielisyyksille.

\section{Kieleen ja kulttuuriin liittyviä huomioita:}

Julkinen arviointi voi olla osalle opiskelijoista haasteellista. Osa opiskelijoista voi myös olla tottunut kirjallisen arvioinnin sijaan suulliseen arviointiin. Rakentavan ja kriittisen palautteen antaminen vaatii sensitiivistä ja hienostunutta kielen käyttöä. Erilaisten rakentavien palautteenantotapojen mallintaminen tukee myönteistä vuorovaikutusta.

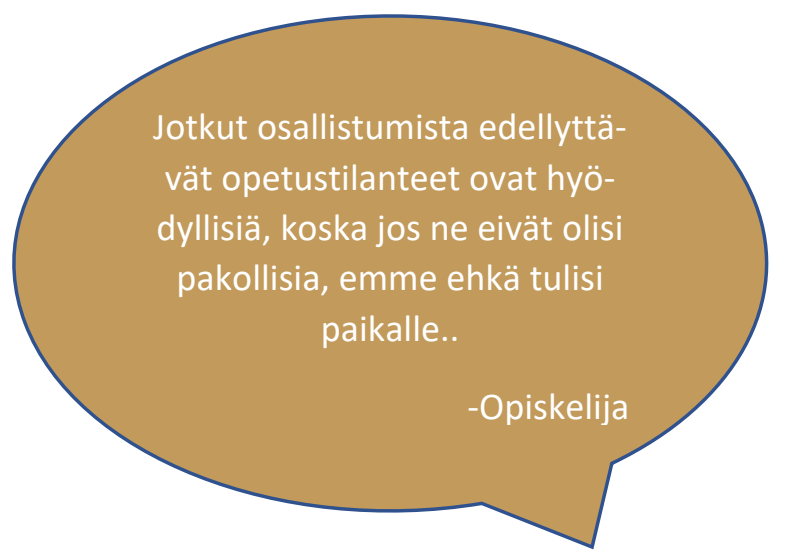

\section{Demot (demonstraatiot) 1}

Demonstraatio- eli demo-opetuksen tavoitteena on tutkia luennon sisältöjä tarkemmin. Demoilla luentojen sisältöihin syvennytään erityisesti siitä kasvatustieteen osa-alueesta käsin, mihin opiskelijaryhmä on suuntautunut (esim. varhaiskasvatus, aikuiskasvatus). Demoilla voidaan käsitellä esimerkiksi luennolla esitettyjä kysymyksiä ja tehtäviä. Pedagogiikkaa käsittelevillä kursseilla demo-opetuksessa tehdään konkreettisia harjoituksia, joiden tavoitteena on syventää ymmärrystä luennolla käsitellyistä aiheista. Vaikka kurssilla voi olla useita eri luennoitsijoita, demoilla työskennellään samassa opetusryhmässä ja saman opettajan johdolla.

\section{Vinkkejä opiskelijalle:}

- Hyvät luentomuistiinpanot ja kirjallisuuteen tutustuminen auttavat demotyöskentelyssä. 
- Parhaimmillaan demot tarjoavat mahdollisuuden yhteiselle keskustelulle, kysymyksille ja ymmärryksen kehittymiselle. Demotyöskentely auttaa myös hahmottamaan kokonaiskuvaa kurssin pääteemoista ja vaatimuksista.

\section{Vinkkejä opettajalle:}

- Oppimisen kannalta voisi olla hyödyllistä, että menneiden luentojen käsittelyn lisäksi demo-opetuksessa alustettaisiin myös tulevia luentoja.

\section{Kieleen ja kulttuuriin liittyviä huomioita:}

Demot vastaavat tutoriaaleja ja pienryhmätyöskentelyä, joissa työskennellään lu-

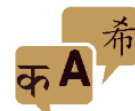
ennolla esiteltyä materiaalia hyödyntäen. Demot voivat myös luoda hyvän tilan kokeilla työskentelyä eri kielillä ja tutkia ideoita hyödyntämällä eri modaliteetteja.

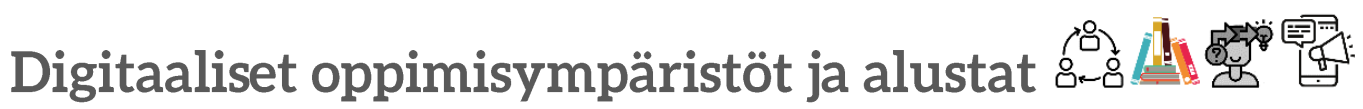

Digitaalisia oppimisympäristöjä hyödynnetään usein etäopiskelussa ja muussa, luokkahuoneen ulkopuolella tapahtuvassa työskentelyssä. Osa kursseista toteutetaan kokonaisuudessaan digitaalisessa oppimisympäristössä (useimmiten Moodle), kun taas osassa kursseista yhdistellään kontaktiopetusta ja verkkotyöskentelyä. Kurssin online-oppimisympäristöstä löytyy kurssin keskeinen materiaali sekä keskustelualue kurssin opiskelijoille. Enenevissä määrin myös tehtävät ja arvioinnit käsitellään digitaalisten oppimisympäristöjen kautta. Yleisiin Moodle-ohjeisiin voi tutustua osoitteessa: https://www.jyu.fi/digipalvelut/fi/ohjeet/moodle-ohjeet

\section{Vinkkejä opiskelijalle:}

- Mitä enemmän käytät kurssin digitaalista oppimisympäristöä, sitä enemmän saat irti koko kurssista. Jaa rohkeasti ajatuksiasi ja ideoitasi, vaikka ne eivät olisikaan vielä täysin valmiita.

- Hyödynnä monipuolisesti online-tilan tarjoamia työskentelymuotoja, kuten chatteja ja keskusteluja. Harjoittele myös erilaisia tapoja osallistua online-työskentelyyn ja pohdi, millaisia erilaisia työskentelyrooleja siihen kuuluu.

\section{Vinkkejä opettajalle:}

- Digitaaliset oppimisympäristöt antavat opiskelijoille suuremman mahdollisuuden valita, milloin he osallistuvat kurssin keskusteluihin.

- Opiskelijoiden kannalta voisi olla hyödyllistä, että myös online- (ja offline-) työskentelyssä panostettaisiin yhteisöllisyyteen. On myös hyvä huomioida, että eri oppimisympäristöjen haltuunotto vaatii opiskelijoilta aikaa. 


\section{Kieleen ja kulttuuriin liittyviä huomioita:}

Digitaaliset alustat ovat loistavia yhteisöllisen oppimisen välineitä. Useat opiskelijat osallistuvat enemmän online-tiloissa, koska opiskeluryhmä ei ole fyysisesti läsnä ja vastauksia voi harkita rauhassa Digitaaliset alustat mahdollistavat myös monikielisen keskustelun ja kääntämiseen liittyvien apuvälineiden ja sanakirjojen hyödyntämisen. Kuten kaikissa opetusryhmissä, myös digitaalisessa oppimisympäristössä yhteisten sääntöjen sopiminen helpottaa työskentelyä (esim. kuinka monta kertaa osallistutaan ryhmäkeskusteluun, mitä tehdään jos tulee ongelmia).

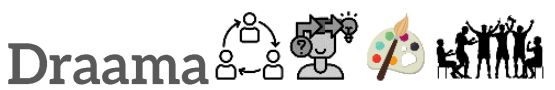

Teoriat heräävät eloon, kun tilanteita ja käsitteitä tarkastellaan draaman keinoin. Draamaharjoitukset auttavat opiskelijoita kehittämään taitojaan soveltaa teorioita käytäntöön. Draamatyöskentelyn avulla voidaan esitellä ja määritellä laaja skaala erilaisia henkilökohtaisia- ja ihmissuhdetaitoja ja se voi rohkaista kehittelemään luovia ratkaisuja vaikeisiin asioihin.

\section{Vinkkejä opiskelijalle:}

- Osalle opiskelijoista draamatyöskentelyyn heittäytyminen on helpompaa kuin toisille. Vaikka et itse olisikaan innokas näyttelijä, voi muiden osallistujien havainnointi herätellä ja kehittää myös omaa ajatteluasi.

- On tärkeää, että jokaista osallistujaa kunnioitetaan osallistumisen tavasta riippumatta koko työskentelyn ajan.

\section{Vinkkejä opettajalle:}

- Draamatyöskentely tarjoaa monenlaisia osallistumisen mahdollisuuksia, kuten luovaa työskentelyä ja kriittistä pohdiskelua.

- Draamatyöskentelyn onnistumisen kannalta onkin tärkeää, että jokainen osallistuja saa valita, millä tavalla haluaa työskentelyyn osallistua. On hyvä myös varmistaa, että jokaisen työskentelytapaa ja -muotoa arvostetaan koko työskentelyn ajan.

\section{Kieleen ja kulttuuriin liittyviä huomioita:<}

Draama tarjoaa tilaisuuden hyödyntää eri kieliä teorioiden ja käytännön luovassa

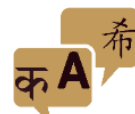
tutkimisessa. Opiskelijat, jotka eivät ole tottuneet työskentelemään draaman keinoin, voisivat hyötyä matalan kynnyksen harjoitteista, jotka orientoivat hyppäämään lopulta mukaan myös draamatyöskentelyyn. Draamatyöskentelyn tarkoitus ja tavoite kannattaa käydä läpi yhdessä osallistujien kanssa, sillä se auttaa heitä tunnistamaan draamatyöskentelyn akateemisen arvon myös kriittisen ajattelun kehittymisen näkökulmasta. 


\section{Etäopiskelu}

Etäopiskeluna suoritettavat kurssit eivät vaadi osallistujien fyysistä läsnäoloa samassa tilassa. Kurssilla voi olla säännöllisiä online-tapaamisia, vaikkakin etäopiskelukurssit suoritetaan pääsääntöisesti täysin tai ainakin osittain itsenäisesti. Etäopiskeluna suoritettavilla kursseilla hyödynnetään useimmiten digitaalisia oppimisympäristöjä, lähteitä ja työtapoja. Katso lisää kohdasta Verkkokurssit.

\section{Vinkkejä opiskelijalle:}

- Vaikka osallistut etäopiskeluna suoritettavalle kurssille, kannattaa kurssin materiaaleista keskustella toisten opiskelijoiden kanssa.

- Opiskelun tukena kannattaa hyödyntää erilaisia opiskelutekniikoita, kuten miellekarttoja, infografiikoita tai oppimispäiväkirjaa. Näin pääset paremmin sisälle kurssin sisältöihin ja omaan oppimisprosessiisi.

\section{Vinkkejä opettajalle:}

- Osa opiskelijoista voi kokea eristäytyneisyyttä ilman opiskeluyhteisöä, ja siksi kurssin suoritukseen sitoutuminen voi olla haastavaa. Yhteisöllisyyttä voidaan kuitenkin rakentaa kannustamalla opiskelijoita muodolliseen ja epämuodolliseen keskusteluun verkkooppimisympäristössä. Kurssin osallistujista voidaan myös muodostaa pareja, jotta jokainen saa opiskelukontaktin.

\section{Kieleen ja kulttuuriin liittyviä huomioita:}

Verkkovälitteisillä ja etäopiskeluna suoritettavilla kursseilla tulee pääsääntöisesti jaettua vain vähän oppimiskokemuksiin liittyviä oivalluksia, mikäli niitä ei erikseen käsitellä. Myös väärinkäsityksiä voi tulla helpommin kuin kasvokkain tapahtuvissa oppimistilanteissa. Digitaalisissa oppimisympäristöissä yhteisten sääntöjen sopiminen helpottaa työskentelyä. Erilaisten modaliteettien hyödyntäminen kurssin tehtävissä voi auttaa osallistujia syventymään kurssin työskentelyyn.

\section{Gallery walk (näyttelykävely, galleriakävely)} Gallery Walk -menetelmässä tila ja liike antavat keskustelulle sisällön ja rakenteen. Näyttelytilaan rakennetaan erilaisia pisteitä ja esityksiä, joiden sisällöistä osallistujat keskustelevat samalla kun siirtyvät pisteeltä toiselle. Näyttelyt voivat sisältää esimerkiksi kuvia, kysymyksiä, pienryhmissä laadittuja postereita tai henkilöitä (esim. elävä kirjasto, vierailevat asiantuntijat). 


\section{Vinkkejä opiskelijalle:}

- On hyvä varmistaa, että tiedät mikä on toiminnan tarkoitus ja miten työskentely etenee.

- Suuren informaatiomäärän omaksuminen lyhyessä ajassa voi olla ylivoimainen tehtävä. Näyttelykävelyn aikana kannattaakin tehdä muistiinpanoja, joihin voit palata vielä näyttelyn jälkeen.

\section{Vinkkejä opettajalle:}

- Galleriakävelyssä liikkumista on hyvä suunnitella tarkkaan, kuten kuinka kauan tulee keskittyä yhteen pisteeseen ja milloin tulee siirtyä eteenpäin. On hyvä myös ilmaista selkeästi, voivatko opiskelijat liikkua tilassa vapaasti oman valinnan mukaan vai onko liikkuminen kontrolloitua (esim. 10 minuuttia jokaisella pisteellä).

- Galleriatyöskentely on tehokas tapa jakaa tutkimustyön tuloksia ja niiden herättämiä kommentteja, ideoita ja kysymyksiä ryhmäläisten kesken.

\section{Kieleen ja kulttuuriin liittyviä huomioita:}

Galleriakävelyssä voidaan hyödyntää eri kieliä ja modaliteetteja, ja siitä voidaan

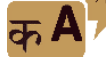
pyrkiä luomaan epämuodollinen tilanne, jossa osallistujat voivat vapaasti vaihtaa ajatuksia ja tutustua toistensa töihin.

\section{Infografiikat (infogrammit)}

Infografiikat ovat erilaisia kuvallisia esityksiä, jotka välittävät ja jäsentävät tietoa. Infografiikan tekeminen vaatii aikaa ja siinä on syytä miettiä tarkkaan, mitä infografiikalla halutaan esittää, miten eri asioiden suhteet ilmaistaan sekä miten kokonaisuus esitetään. Valmiita infografiikoiden pohjia löytyy esimerkiksi: Canva, Easel.ly, Infogr.am, Piktochart \& Venngage.

\section{Vinkkejä opiskelijalle:}

- Infografiikat tarjoavat tilaisuuden kriittiselle ja monipuoliselle ajattelulle. Kannattaa tutustua erilaisiin infografiikoihin ja pohtia, mikä omasta mielestä vaikuttaa selkeimmältä ja millaista infografiikkaa oman aiheen/teeman/asian kohdalla kannattaisi käyttää. On hyvä myös kokeilla erilaisia versioita ennen lopullista valintaa.

\section{Vinkkejä opettajalle:}

- Työskentelymuotona infografiikat kehittävät ja vaativat kuvanlukutaitoja. Tehokkaan infografiikan tuottaminen vaatii asian kokonaisvaltaista ymmärrystä ja tärkeän tiedon erottamista. 
- Erilaisten infografiikoiden käyttäminen mallina voi auttaa opiskelijoita oivaltamaan, miten infografiikoita käytetään ja mikä niiden merkitys on oppimisen kannalta.

\section{Kieleen ja kulttuuriin liittyviä huomioita:}

Infografiikan laatimisessa tarvitaan vähemmän kieltä, mutta se vaatii huolellista

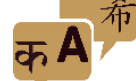
ajattelua, valmistautumista, ymmärrystä ja esittelytaitoja. Opiskelijat, jotka ovat tottuneita suullisiin ja kirjallisiin tehtäviin todennäköisesti hyötyvät lyhyestä keskustelusta, jossa käydään läpi infografiikoiden merkitys esityksen muotona. Infografiikka on mahdollistaa myös eri kielten yhdistämistä luovalla tavalla.

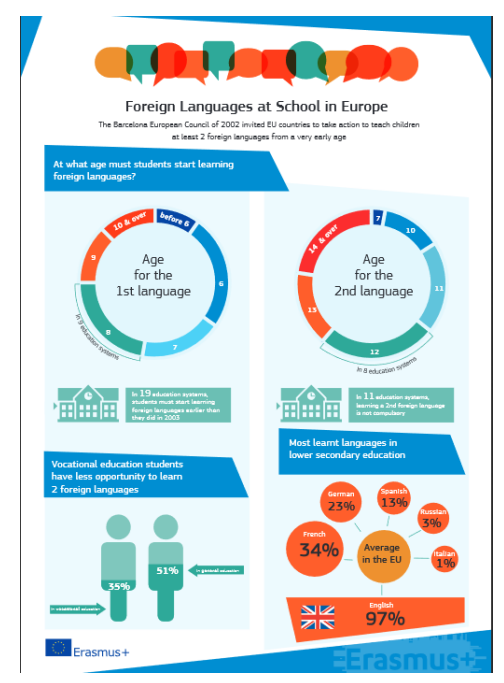

Kuva 2: https://eacea.ec.europa.eu/nationalpolicies/eurydice/sites/eurydice/files/infographic_languages_2017_09_25_0.pdf

\section{Integroivat opiskelumuodot/ opiskelutekniikat}

Integroivissa eli yhdistelevissä opiskelumuodoissa hyödynnetään ristiin eri kursseilla tapahtuvaa työskentelyä. Esimerkiksi yhden kurssin aikana luettu kirjallisuus voi tukea toisen kurssin keskustelua ja kirjallisia tehtäviä, tai jonkin kurssin puitteissa laadittua tuntisuunnitelmaa voidaan hyödyntää ja kehitellä pitemmälle opetusharjoittelussa. Integroivat opiskelumuodot tukevat entistä holistisempaa lähestymistapaa opiskeluun ja rohkaisevat opiskelijoita tutkimaan samaa ilmiötä useista eri näkökulmista.

\section{Vinkkejä opiskelijalle:}

- Opiskelun ideaalitilanteessa eri kurssit täydentävät toisiaan, mutta useimmiten on kiinni opiskelijasta itsestään, miten yhteydet löydetään ja miten niitä osataan hyödyntää. Integroivilla opiskelutekniikoilla voit syventää omaa ajatteluasi. Aihealueen ja aiempien 
kurssien sisältöjen yhteyksien kriittiseen pohdintaan kannattaa käyttää aikaa. Kun yhteyksien luomisesta tulee tapa, on helpompaa nähdä, kuinka opintojesi eri osat sopivat yhteen.

\section{Vinkkejä opettajalle:}

- Osalle opiskelijoista on haastavampaa hahmottaa eri kurssien välisiä yhteyksiä kuin toisille. Se mikä on opettajalle itsestäänselvyys, voi olla opiskelijoille mysteeri. Mikäli mahdollista, anna opiskelijoiden työstää eri kurssien välisiä yhteyksiä oman kurssisi alussa tai lopussa. Tämä auttaa opiskelijoita rakentamaan suurempaa kuvaa.

\section{Kieleen ja kulttuuriin liittyviä huomioita:}

Integroivien opiskelumuotojen avulla tuetaan akateemisen kielen/kielitaidon ke-

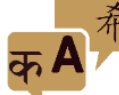
hittymistä, koska avainkäsitteitä toistetaan ja niitä laajennetaan. Yhdistelevät opiskelutekniikat myös auttavat kehittämään akateemista ajattelua, sillä opiskelijat palaavat avainkäsitteisiin ja työstävät niiden välisiä yhteyksiä ja ristiriitoja sekä kriittisiä näkökantoja. Avainsanojen ja -fraasien tähdentäminen tai sanapankin kehittäminen voi auttaa opiskelijoita tulemaan tietoisemmiksi käyttämästään kielestä. Sanapankit voivat olla yksi- tai monikielisiä, käsin kirjoitettuja tai digitaalisia, luovasti tai perinteisesti esitettyjä.

\section{Itsenäinen opiskelu 1 1}

Osa kursseista järjestetään itsenäisen opiskelun kursseina. Tällä tarkoitetaan sitä, että opiskelija voi suorittaa kurssin osallistumalla tenttiin tai laatimalla oppimistehtävän. Suoritustavat määritellään joka vuosi opinto-ohjelmassa. Mikäli tarvitset opettajalta lisätietoja tehtävistä ennen kurssin alkua, katso tarkemmat toimintaohjeet kurssin kohdalta.

\section{Vinkkejä opiskelijalle:}

- Itsenäisen opiskelun kurssi voi vaatia useita työskentelytunteja viikoittain. Tämän lisäksi voit vielä tarvittaessa sopia tapaamisia opettajan kanssa tai lähettää sähköpostia, mikäli kurssin aikana herää kysymyksiä tai tarvetta tarkennuksille.

- Itsenäisen työskentelyn kursseja voit useimmiten suorittaa omaan tahtiisi ja oman aikataulusi mukaan. Aikataulu kannattaa suunnitella niin, että itsenäisen opiskelun kurssi sopii muihin, saman lukukauden oppimistavoitteisiin.

- Yhteistyö toisen, itsenäisen opiskelun kurssia suorittavan opiskelijan kanssa voi auttaa sinua asettamaan itsellesi deadlineja ja pitämään yllä opiskelumotivaatiota. 


\section{Vinkkejä opettajalle:}

- Itsenäisen opiskelun kursseilla on tärkeää, että osaamistavoitteet ja asiasisällöt ovat selkeät, eikä opiskelijalle jää epäselvyyksiä.

- Itsenäisen työskentelyn lisäksi voisi olla hyödyllistä, että opiskelijat tapaisivat opettajan joko ryhmätapaamisten tai kurssin alkutapaamisen muodossa.

\section{Kieleen ja kulttuuriin liittyviä huomioita:}

Monet opiskelijat ovat itsenäisen työskentelyn sijaan tottuneempia valmiiksi strukturoituihin kursseihin, jotka sisältävät vuorovaikutusta opettajan kanssa. Mikäli itsenäinen opiskelu on opiskelijalle uutta, on hyödyllistä painottaa, että kurssin suorittaminen vaatii aikatauluttamista ja motivaatiota. Erilaiset "tarkastuspisteet" tai "pysäkit" voivat auttaa opiskelijoita orientoitumaan joustavuuteen ja itsenäisen työskentelyn vaatimuksiin laajemmalla aikavälillä.

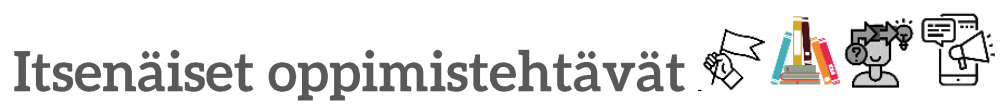

Itsenäisten harjoitusten tekeminen on oleellinen osa opiskelua. Tällaisissa harjoituksissa työstetään ja yhdistellään kurssin sisältöjä, jotta kurssin suorittajat saavat hyvän yleiskuvan kurssin aiheista.

\section{Vinkkejä opiskelijalle:}

- Itsenäisten töiden tekemiseen kannattaa varata aikaa. Ne tarjoavat mahdollisuudentutkia, mitä tiedät, mitä olet oppinut ja miten olet kehittynyt kurssin aikana. Kokeile erilaisia opiskelumenetelmiä kehittääksesi omaa ajatteluasi ja laajentaaksesi omia opiskelutapojasi.

\section{Vinkkejä opettajalle:}

- Opiskelijat hyötyvät siitä jos heille tehdään ymmärrettäväksi kuinka itsenäiset työt tukevat kurssin muuta työskentelyä.

- On myös tärkeää kertoa opiskelijoille, miten itsenäiset työt arvioidaan ja ovatko ne pakollinen osa kurssin suoritusta, vaikka ne eivät olisi osa kurssin loppuarviointia.

\section{Kieleen ja kulttuuriin liittyviä huomioita:}

Kannattaa pohtia, miten eri kieliä voisi käyttää, ja mitkä kielet ja opiskelutavat tu-

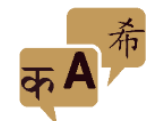
kevat oppimistasi parhaiten. On hyödyllistä ajatella useilla eri kielillä, sillä se voi auttaa hahmottamaan eri näkökulmia. Kun kartoitat ymmärrystäsi, käytä kieltä/kieliä, joiden avulla työskentely tuntuu mukavimmalta. Kun aloitat palautettavan tehtävän valmistelun, 
tarkista, miten avainkäsitteet ja -termit ilmaistaan tehtävältä vaaditulla kielellä. Vasta kun sisältö on selkeä, siirry ajattelemaan sillä kielellä, millä lopullinen tehtävä esitetään.

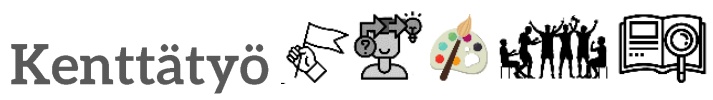

Kenttätyöllä tarkoitetaan fyysistä siirtymistä yliopiston seinien ulkopuolelle, "kentälle", jossa kiinnostuksen kohteena oleva asia tai ilmiö on osa luonnollista ympäristöään. Kenttä voi olla esimerkiksi metsä, suo tai puro, mikäli tavoitteena on tutkia luontoympäristöä. Kasvatustieteessä kenttä voi olla kasvatuksellinen tai koulutuksellinen ympäristö kuten koulu, päiväkoti tai museo, jossa tavoitteena on kerätä sosiaalista aineistoa. Kenttätyöskentelyssä voidaan hyödyntää useita eri aineistonkeruumenetelmiä.

\section{Vinkkejä opiskelijalle:}

- Jotta saisit kenttätyöskentelystä eniten irti, valmistaudu aineistonkeruuseen etukäteen. Tiedosta, mikä on vierailun tarkoitus ja mitä sinulta odotetaan. Tiedosta myös, että aina kun astutaan tutkimuskentälle, tullaan samalla myös vaikuttaneeksi siihen jollakin tavalla. Ideaalitilanteessa aiheutettu häiriö on mahdollisimman pieni.

\section{Vinkkejä opettajalle:}

- Opiskelijat hyötyvät selkeistä toimintaohjeista, joissa on kuvattu kenttätyöskentelyn toteuttaminen, tehtävän tarkoitus sekä opiskelijoiden mahdolliset roolit.

\section{Kieleen ja kulttuuriin liittyviä huomioita:}

Osallistujilla on moninaisia kulttuurisia kokemuksia, ja onkin syytä ohjeistaa tar-

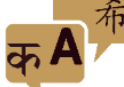
kasti, mitä kenttätyöltä odotetaan, miten kentällä tulee käyttäytyä ja miten työskentelystä saa mahdollisimman paljon irti. Kannattaa käydä yhdessä läpi esimerkiksi, miten kommunikoidaan yhteisön kanssa, miten tehdään muistiinpanoja, mikä voisi olla sopimatonta (kuten lapsien valokuvaaminen ilman lupaa), voidaanko lasten kokemuksia kysyttäessä käyttää eri kieliä ja kuinka vastaukset raportoidaan.

\section{Keskustelukartta tai hiljainen dialogi}

Keskustelukartan avulla voidaan luoda energisoiva, dynaaminen ja ajatuksia herättävä keskustelu täysin ilman puhetta. Lähestymistavan ydinajatuksena on systemaattinen, yhteinen ajattelu, jolla pyritään herättämään monipuolisesti erilaisia ideoita monimutkaisesta aiheesta. Työskentelyn alussa osallistujat kerääntyvät suuren paperin ympärille. Osallistujat lisäävät vuoron perään ajatuksiaan paperille, jolloin ajatuksen kulku ja asioiden yhteydet tulevat näkyviin. Paperi toimii myös visuaalisena työkaluna myöhemmälle 
keskustelulle ja reflektiolle. Eri näkökulmat tarjoavat ideoita monimutkaista asiaa käsittelevään yhteiseen keskusteluun. Seuraavista linkistä löytyy hyödyllistä tietoa, miten lähestymistapaa voidaan hyödyntää käytännössä https://philipwallis.wordpress.com/2012/02/14/conversation-mapping/).

Hiljaisen ryhmän miellekartta on eräänlainen variaatio samasta työtavasta. Molemmissa aktiviteetissa hyödynnetään samansuuntaisesti fyysistä liikettä ja kollaboratiivista ajattelua. Alla olevasta linkistä löytyy tietoa, kuinka aktiviteettia voidaan soveltaa luokkahuoneessa. https://www.mindsettlers.com/guide/AjqsZOtk3Y6aEWwkEqqYW

\section{Vinkkejä opiskelijalle:}

- Jokainen opiskelija voi valita värin, jolla lisää kommentteja keskustelukarttaan. Pysähdy ja reflektoi, ennen kuin lisäät kommentin jo olemassa olevaan ajatusketjuun tai aloitat kokonaan uuden ketjun.

- Vältä yhteyksien piirtämistä eri ketjujen välille, sillä se voi sekoittaa taustalla vaikuttavia käsityksiä. Mahdollisia ketjujen välisiä yhteyksiä voidaan lisätä jatkokeskustelussa.

\section{Vinkkejä opettajalle:}

- Voimakkaat kysymykset tai väitteet keskustelukartan keskellä auttavat herättämään erilaisia ajatteluprosesseja. Useimmiten saman kartan kysymykset käsittelevät samaa aihetta tai teemaa.

- Työskentelyvaiheessa kannattaa kävellä ympäriinsä ja tarkkailla, onko hiljainen työskentely opiskelijoille luontevaa. Joskus opiskelijat vain aloittavat keskusteluja, mutta tavoitteena on kommunikoida ja tuottaa jatkuvasti uusia ideoita kirjoitetun kielen välityksellä ja siten ylläpitää työskentelyä. Opiskelijoita kannattaa myös rohkaista kävelemään ympäriinsä ja osallistumaan jokaiseen keskustelukarttaan.

\section{Kieleen ja kulttuuriin liittyviä huomioita:}

Tässä aktiviteetissa voidaan hyödyntää mitä tahansa ryhmälle yhteistä työsken-

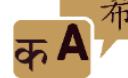
telykieltä. Monille opiskelijoille työskentelytapa voi olla uusi, mutta selkeiden ohjeiden avulla he useimmiten sopeutuvat ja osallistuvat hyvin. Tämä opiskelumenetelmä toimii erityisen hyvin monikulttuurisissa ryhmissä, sillä se hidastaa dialogin vauhtia ja antaa osallistujille aikaa reflektoida omaa kommenttiaan ennen sen lisäämistä. Monikielisissä ryhmissä keskustelukarttoihin voidaan lisätä eri kieliä, ja jatkokeskustelussa opiskelijat voivat koota moninaisia, eri kielillä esitettyjä ideoita, kysymyksiä ja mielipiteitä.

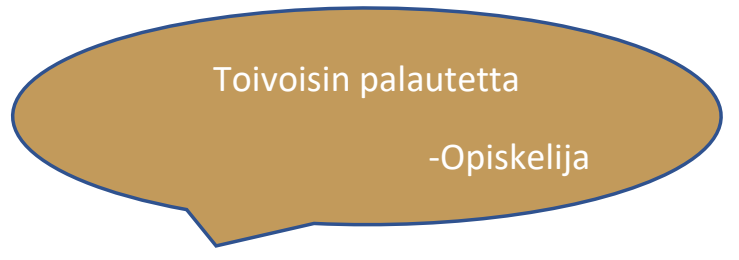




\section{Kirjatentti/eTentti 14 照}

Joillakin kursseilla on käytössä kirjatentti tai eTentti, joka voi olla yksi osa kurssin suoritusta. Osa kursseista on suoritettavissa kokonaan kirjatentillä tai eTentillä. Lisätietoa JYU:n eTenteistä on saatavilla alla olevasta linkistä: https://help.jyu.fi/jp?id=kb_article\&sys_id=b07e69d2dbf6d4d07b7b2b4305961967

\section{Vinkkejä opiskelijalle:}

- Kun luettavana on kokonainen kirja, kannattaa ensisijaisesti pyrkiä löytämään kirjan pääideat ja taustaoletukset.

- Tekstikirjat tarjoavat tyypillisesti vain yksittäisiä katsauksia ja näkökulmia käsiteltävään aiheeseen, ja samalla lähestymistavan kriittinen tarkastelu ja taustoitus jäävät tekstissä vähälle.

- Akateemiset kirjat puolestaan pyrkivät ilmiön kokonaisvaltaiseen tarkasteluun. Tällöin tekstissä käsitellään ilmiön ideologisten juurien ja käytännön sovellusten lisäksi myös kriittinen näkökulma. Molemmissa tapauksissa lukijan täytyy pyrkiä kriittisyyteen arvioidessaan kirjassa esitettyjä ideoita ja ajatuksia.

\section{Vinkkejä opettajalle:}

- Opiskelijoista voi olla haastavaa löytää kirjan sisällöstä keskeiset asiat ja sitä kautta tietää, miten yksityiskohtaisesti kirjaa tulisi opiskella.

- Opettajana kannattaa olla selvillä, millaisia hyötyjä ja haasteita eri tyyppiset kirjat antavat akateemiselle opiskelulle. Yliopiston tekstikirjat eivät todennäköisesti kannusta kriittiseen ajatteluun. Akateemiset kirjat ilmaisevat omat lähtöoletuksensa, mutta lukijan tulee tietää, mistä/miten ne löytyvät.

\section{Kieleen ja kulttuuriin liittyviä huomioita:}

Kirjatentit eivät ole universaali opiskelumuoto. Yhden lähteen lukeminen ja sen

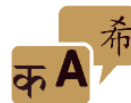
perusteella vastaaminen voi tuntua laajoihin aineistoihin tottuneille opiskelijoille vieraalta ajatukselta. Lisäksi kokonaisen kirjan lukeminen voi tuntua vieraalta, jos aiemmissa opinnoissa on tottunut valmistautumaan tentteihin esimerkiksi luentomateriaalien avulla.

\section{Kirjoittamisen strategiat 1}

Erilaiset kirjoittamisen strategiat auttavat kehittämään tekstiä, oli se sitten kirjoitettua tai suullista. Kirjoittamisen strategioita on olemassa monenlaisia. Osa strategioista, kuten aivoriihi, vapaa kirjoittaminen ja kuutiointi, auttaa tuottamaan ideoita. Osa strategioista, kuten ryhmittely, miellekartat, listat, vertailut ja vastakkainasettelut, taas auttavat jäsentämään ideoita ja rakentamaan tekstin kokonaiskuvaa. Kun kirjoittamisprosessi aloitetaan 
ideoiden tuottamisella ja niiden järjestämisellä tekstin tavoitteen kannalta oleellisella tavalla, tarvitaan prosessin loppuun saattamisessa enää vain tekstin muokkaamista. Kirjoittamisen strategioita hyödyntämällä viimeistely vaatii vähemmän aikaa, ja tekstistä tulee parempaa.

\section{Vinkkejä opiskelijalle:}

- Hyvää tekstiä saa harvoin aikaan vain yhdeltä istumalta. Vaikka varsinaisen kirjoittamistyön lykkääminen voi olla turhauttavaa, huolellinen suunnittelu johtaa kuitenkin parempaan lopputulokseen. Etsi itsellesi siis hyvä tila, ja käytä prosessiin aikaa.

- Kokeile erilaisia strategioita jotta huomaat, mitkä sopivat juuri sinulle. Lisäksi kirjoittamisprosessin eri vaiheissa kannattaa hyödyntää erilaisia strategioita. Osalle paperin ja kynän hyödyntäminen voi olla luontevaa, kun taas osa pitää enemmän digitaalisista välineistä.

\section{Vinkkejä opettajalle:}

- Tekstin luonnosten (tai luonnosten osien) esitteleminen voi auttaa opiskelijoita hahmottamaan suunnitteluvaiheen yhdeksi tärkeäksi kirjoittamisprosessin osaksi.

\section{Kieleen ja kulttuuriin liittyviä huomioita:}

Ideoiden tuottamisen ja kehittelyn vaiheessa voi olla hyödyllistä ajatella eri kielillä.

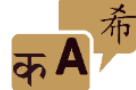
Kun prosessissa edetään varsinaiseen kirjoittamisvaiheeseen, kannattaa kuitenkin käyttää säännönmukaisesti vain yhtä kieltä, jotta tekstistä tulee hyvää. Palautteen saaminen kirjoitusprosessin aikana voi olla erittäin hyödyllistä. Erilaiset kirjoittamisen strategiat voivat auttaa opiskelijoita jakamaan ja tuottamaan ideoita, sekä kehittelemään ja tuottamaan yhdessä kirjoitettua tekstiä.

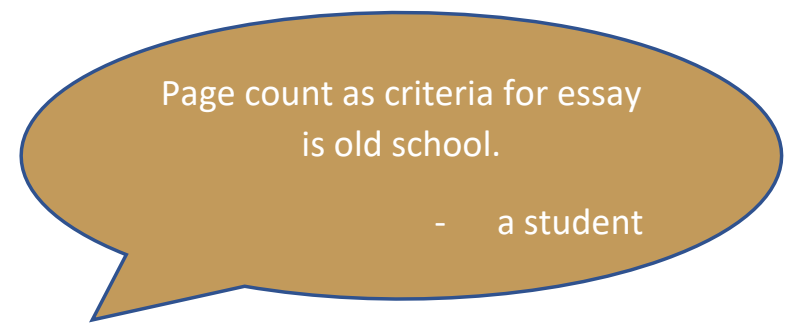

\section{Kirjoitustehtävä/essee 11.}

Kirjoitustehtävän tai esseen tulisi olla yhtenäinen teksti, jolla on johdonmukainen, systemaattinen rakenne (johdanto, varsinainen sisältö, kokoava päätösosa). Kirjoitustehtävät sisältävät usein koonnin kurssin keskeisestä sisällöstä (esim. luennot, kirjallisuus), mutta 
myös omaa kriittistä ajattelua. Vaikka akateeminen kirjoittaminen on vaativaa ja se sisältää useita vaiheita (suunnittelu, luonnostelu, editointi), on se myös tehokas tapa oppia. Akateeminen kirjoittaminen auttaa opiskelijoita kehittelemään ja yhdistelemään omia ideoitaan lähdemateriaalien ideoihin. Tämä prosessi vaatii aikaa. Ks. lisää osoitteesta https://www.jyu.fi/edupsy/fi/opiskelu/opiskeluohjeet/pikaohjeet/essee

\section{Vinkkejä opiskelijalle:}

- Kun suunnittelet esseetäsi, määrittele ja rajaa aihe tarkasti. Etsi oleellista kirjallisuutta ja/tai käytä tehtävänannossa mainittuja lähteitä. Pidä mielessä, että esseellä tulisi olla selkeä ja yhtenäinen rakenne, ja käytetyn kielen tulisi olla tyyliltään muodollista. Akateemiseen tyyliin lähdeviitteiden tulee olla mukana tekstissä ja tekstin lopussa tulee olla lähdeluettelo, joka on laadittu APA 7 ohjeiden mukaan.

- Lisätietoja saat JYU:n Monikielisen akateemisen viestinnän keskuksen MOVI:n sivuilta https://movi.jyu.fi/en/instructions/maturity-exam/advice-for-writing-an-essay-typetext

\section{Vinkkejä opettajalle:}

- Opiskelijat voivat häkeltyä akateemisen kirjoittamisen vaatimuksista, varsinkin jos työskentely tapahtuu vieraalla kielellä.

- Huolellinen suunnittelu ja luonnosten tekeminen voi auttaa opiskelijoita kehittämään ideoitaan. Onkin hyvä arvioida tarkkaan, mikä voisi olla tekstille sopiva pituus, ja tarvitsevatko opiskelijat apua ymmärtääkseen erilaisia esseetyyppejä tai -kysymyksiä (selitä, vertaile, arvioi kriittisesti) ja mitä niissä vaaditaan. Voi myös olla hyvä mallintaa esseen kirjoitus- ja suunnitteluprosessia.

\section{Kieleen ja kulttuuriin liittyviä huomioita:}

Hyvän akateemisen lukutaidon kehittyminen vaatii aikaa ja harjoittelua. On hyvä

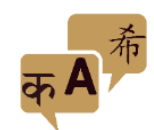
miettiä tarkkaan, milloin on akateemisten taitojen kehittymisen kannalta tärkeää noudattaa tarkkoja ohjeita ja milloin taas on tärkeää antaa opiskelijoille tilaa kehittää omaa ääntään. Kirjoitetut tekstit eivät myöskään ole ainoa tapa, jolla opiskelijat voivat osoittaa oppimistaan.

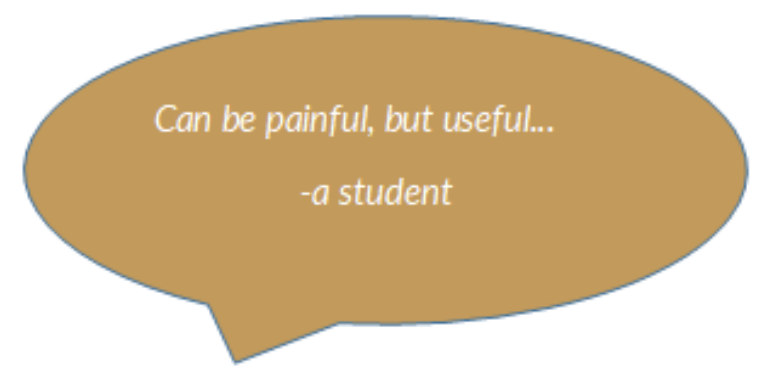




\section{Kommentoitu kirjallisuusluettelo 1}

Kommentoitu kirjallisuusluettelo (tai kommentoitu lähdeluettelo) on akateemiseen tyyliin laadittu kirjallisuusluettelo, joka sisältää varsinaisen lähteen (esim. kirjat, artikkelit, arvostelut) lisäksi lyhyen kommentin kustakin mainitusta lähteestä. Kommentti voi olla tyyliltään kuvaileva, informatiivinen, analyyttinen ja/tai kriittinen. Tyyliltään kriittisessä kommentissa tarkastellaan lähteen vahvuuksia ja heikkouksia. Kommentti voi sisältää myös opiskelijan omaa pohdintaa, kuten onko lähde käyttökelpoinen tai tarjoaako se uusia näkökulmia.

\section{Vinkkejä opiskelijalle:}

- Akateemisen lähdeviittaustekniikan omaksuminen vaatii aikaa. Tämän tehtävän avulla saat hyvää harjoitusta lähdeluettelon laatimiseen.

- Tämän harjoituksen avulla pääset alkuun teemakohtaisten akateemisten lähteiden etsinnässä sekä harjaannutat samalla akateemisia luku- ja tiedonhakutaitojasi.

- Jos sisällytät kommenttiisi suoria lainauksia lähteestä, muistathan lainausmerkit! Mainitse myös tarkka sivunumero.

- Kommentoitujen kirjallisuusluettelojen laatiminen on myös kätevä tapa kerätä kaikki opintojesi aikana lukemasi aineisto ja saamasi ideat samaan paikkaan.

\section{Vinkkejä opettajalle:}

- Opiskelijoille on hyvä tarkentaa, onko tehtävässä tavoitteena keskittyä teeman tarkasteluun vai saavatko he itse valita, mitä he kommenteissaan tarkastelevat.

- Kommentoidun kirjallisuusluettelon mallin näkeminen voi olla opiskelijoille hyödyllistä.

\section{Kieleen ja kulttuuriin liittyviä huomioita:}

Kommentoitu kirjallisuusluettelo voi toimia kannustimena tarttua erikielisiin lähteisiin. Opiskelijoita voisi esimerkiksi ohjeistaa käyttämään kahdella tai kolmella eri kielellä kirjoitettuja lähteitä. On kuitenkin hyvä antaa selkeät kriteerit, mikä on hyvä akateeminen lähde, esim. akateemisessa lehdessä julkaistun artikkelin ja anonyymisti kirjoitetun tekstin erot.

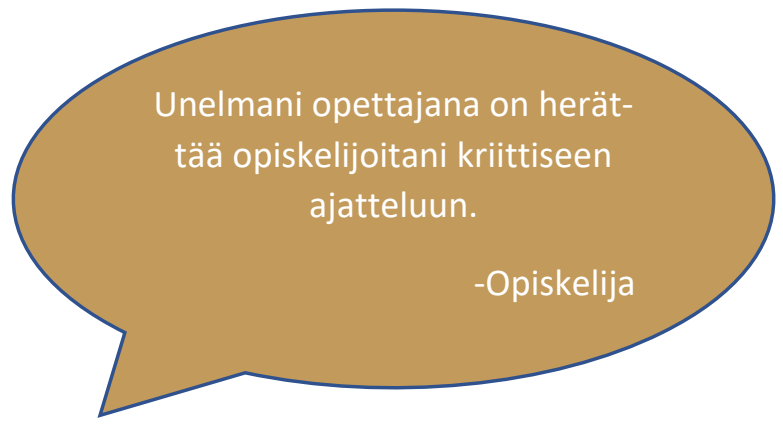




\section{Kriittinen ajattelu哭}

Kriittinen ajattelu on akateemisen työskentelyn ja opiskelun perusta. Kriittisellä ajattelulla tarkoitetaan eri näkökulmien tarkastelua, omien lähtöoletusten sanallistamista ja vaikeiden kysymysten kysymistä. Kriittinen ajattelun oppiminen on kokonaisvaltainen prosessi, jossa taito kehittyy harjoittelun myötä. Kriittinen ajattelu on yhdistelmä eri taitoja, kuten päättelyä, analysointia ja arviointia, mutta myös taipumusta avoimuudelle ja tiedonhalulle. Kriittisen ajattelun hyvänä alkupisteenä voidaan pitää kysymystä 'miksi'.

\section{Vinkkejä opiskelijalle:}

- Kriittinen ajattelu näkyy akateemisessa opiskelussa eri tavoin, ja sen kehittyminen vaatii aikaa ja harjoittelua. Kaikki akateemiseen opiskeluun liittyvät tehtävät kehittävät kuitenkin kriittistä ajattelua, jokainen omalla tavallaan!

- Kannattaa tutustua eri tutkijoiden tapoihin kirjoittaa samasta aiheesta, ja pyrkiä löytämään näkökulmista yhtäläisyyksiä ja eroavaisuuksia. Todennäköisesti huomaat, että yksi tutkija painottaa sellaista asiaa, joka puolestaan toisen tutkijan tekstistä puuttuu kokonaan.

\section{Vinkkejä opettajalle:}

- On hyvä huomata, että virheiden tekeminen ja mielipiteiden muuttuminen kuuluvat oppimisprosessiin. Näkökulmien julkinen jakaminen ja kritisoiminen voi olla osalle opiskelijoista vaikeaa, varsinkin jos ryhmän toimintakulttuuri ei ole suotuisa ympäristö eri näkökantojen tutkimiselle.

- Opiskelijoita hyödyttää kuulla toistensa kriittistä itsereflektiota, sillä näin he myös itse alkavat kehittää omaa kriittistä näkökantaansa.

\section{Kieleen ja kulttuuriin liittyviä huomioita:}

Kriittinen ajattelu voi helposti sekoittua kritisointiin. Kritisoinnilla tarkoitetaan kuitenkin vääryyden tai väärän mielipiteen osoittamista. Kriittinen ajattelu taas on ensivaikutelmien ohittamista ja pyrkimystä ymmärtää, mitä on sanottu, ja sitä kautta pyrkimystä muodostaa omia, tarkkaan harkittuja mielipiteitä. Kriittinen ajattelu voi olla erityisen haasteellista niille, jotka ovat tottuneet toisintamaan auktoriteettien sanoja ja ideoita. Eri kielillä ajatteleminen voi olla yksi tapa ajatella erilaisista näkökulmista ja herätellä kriittistä ajattelua. Kriittinen ajattelu voi myös herättää uusia kysymyksiä ja saada opiskelijoita pohtimaan, ovatko he/miten he ovat samaa tai eri mieltä muiden kanssa. The Manchester Phrasebank tarjoaa kattavan kokoelman englanninkielisiä fraaseja, joiden avulla voi ilmaista kriittistä ajattelua: http://www.phrasebank.manchester.ac.uk/being-critical/ 


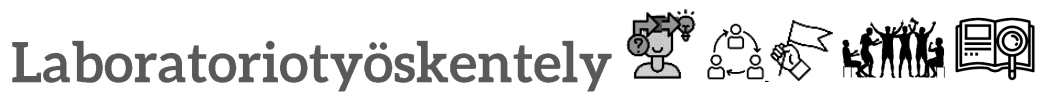

Laboratoriossa opiskelijat voivat työskennellä itsenäisesti tai ryhmässä. Laboratoriotyöskentelyn tavoitteena on toteuttaa luonnontieteellisiä kokeita käytännössä, tutustua laboratoriovälineistöön ja harjoitella tulosten analysointia ja raportointia. Opettajankoulutuksessa laboratoriotyöskentelyssä opetellaan myös luonnontieteisiin soveltuvia pedagogisia menetelmiä.

\section{Vinkkejä opiskelijalle:}

- Laboratoriossa sinulla on kaksoisrooli: toisaalta toteutat tutkimusta käyttäen omia taitojasi, ja toisaalta mietit taitoja ja opetushetkiä koulukontekstin näkökulmasta.

- Kun teet muistiinpanoja tutkittavasta ilmiöstä, merkitse muistiin myös tieteellisiä taitoja, joita ajattelet lasten tarvitsevan kokeen suorittamiseksi: onko kokeen kannalta merkityksellisintä seurata ohjeita tarkasti? Vai löytää omia ratkaisuja? Onko tärkeää tehdä vertailua eri olosuhteista vai ennakko-oletuksia reaktioon johtavista syistä?

\section{Vinkkejä opettajlle:}

- Osalla opiskelijoista on ennakko-oletuksenasia, että määrällinen tutkimus on heidän taitoihinsa nähden liian vaikeaa. Koska peruskoulussa hyvin harvoin tehdään numeerista analyysiä kokeiden avulla selvitetyistä yhteyksistä, suhteiden yksinkertaisuus voikin tullakoitua opiskelijalle positiivisena yllätyksenä ja tarjota positiivisen oppimiskokemuksenksi oppimiskokemukseksi.

- Mikäli teette laboratoriossa harjoituksia, jotka eivät sovellu peruskouluikäisille lapsille (kuten myrkyllisten kemikaalien käyttö, tulitikkujen käyttö, vaikeat käsitteet), on hyvä mainita siitä opiskelijoille, jotta on selvää, ettei harjoitus sovellu kouluympäristöön.

- Työstäkää yhdessä, mitä tulosten raportointi voi käytännössä tarkoittaa miltä tulosten raportointi näyttää ja avatkaa sanallisesti, miten kokeellinen data (opiskelijoiden havainnot) ja teoreettinen malli (millainen hypoteesi tehtiin ja toteutuuko se datassa) $\mathrm{yh}$ distetään.

\section{Kieleen ja kulttuuriin liittyviä huomioita:}

Laboratoriotyöskentely perustuu useimmiten tutkimuskysymykseen. Jos kysy-

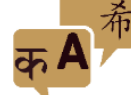
mys on epäsuora ("Tutkitaan erilaisten papereiden ominaisuuksia"), on hyvä aloittaa teeman purkamisella täsmällisiksi kysymyksiksi ("Kuinka paljon vettä erilaiset, $10 \mathrm{~cm} \times 10 \mathrm{~cm}$ -suuruiset paperit imevät?"), jotta päästään jyvälle, mitä kokeessa tehdään. Laboratoriotyöskentelyn ohjeet ovat erilaisissa muodoissa: osa ohjeista on reseptimuodossa (vrt. keittokirja) ja osa voi olla hyvinkin avoimia, jolloin opiskelijoille annetaan enemmän vapauksia kokeen toteuttamiseen. Keittokirja-tyyliset ohjeet mallintavat laboratoriotyoskentelyssä käytettävää kieltä (tekniikoiden ja välineiden kuvaukset), kun taas avoimet ohjeet kannustavat ongelmanratkaisuun. 


\section{Learning café ja pedagoginen kahvila 品}

Oppimistilanne voidaan järjestää epämuodolliseksi ympäristöksi, jossa keskusteluja käydään pienissä ryhmissä 'kahvipöydän' ympärillä. Joissakin learning café -harjoituksissa osallistujat voivat liikkua vapaasti eri pöytien välillä, kun taas joissakin harjoituksissa pöydän ääressä käytävällä keskustelulla on ohjaaja, ja liikkuminen eri teemapöytien välillä on organisoitu tarkemmin. Learning café -työskentelyssä oppimista tapahtuu ideaalitilanteessa kriittisten keskustelujen kautta. Pedagogisessa kahvilassa keskitytään pedagogiikan kehittämiseen.

\section{Vinkkejä opiskelijalle:}

- Learning café -työskentely onnistuu parhaiten, kun jokainen osallistuu siihen aktiivisesti jakaen ideoita, kuunnellen ja kysyen avoimia kysymyksiä.

\section{Vinkkejä opettajalle:}

- Osallistujia voi hyödyttää, että he pystyvät valmistautumaan learning café -harjoitukseen etukäteen ja että he tietävät, mitä tuleman pitää. Opettajan vastuulla on keskusteluaiheiden ja orientoivien kysymysten huolellinen suunnittelu, sekä yleisen alustuksen pitäminen ennen osallistujien jakamista pienempiin ryhmiin.

\section{Kieleen ja kulttuuriin liittyviä huomioita:}

Työskentelytilanteen tulisi kannustaa jokaista osallistumaan kielitaidoista huolimatta. Mikäli learning café -työskentely on osallistujille uutta, keskustelun ylläpitoa voi helpottaa pöydässä olevalla, käyttökelpoisten fraasien 'ruokalistalla'. On hyvä varata työskentelylle tarpeeksi aikaa, jotta opiskelijat kokevat tilanteen tarpeeksi miellyttäväksi ilmaistakseen itseään. Muistiinpanojen kirjoittaminen keskustelujen aikana auttaa jokaista pysymään mukana työskentelyssä. Mikäli learning café -työskentely on osallistujille uutta, voi myös olla hyödyllistä pohtia harjoituksen jälkeen, mitä harjoituksen aikana opittiin.

\section{Luennot}

Luennot ovat akateemisen opiskelun perinteisin muoto. Luennoilla esitellään kurssin teoreettinen sisältö ja aihealueeseen liittyviä esimerkkejä. Luennot järjestetään julkisina joko fyysisessä tilassa (esim. luentosalissa) tai verkon välityksellä. Luentomonisteet/luentodiat ovat saatavilla joko etukäteen tai luennon jälkeen. Luentojen aktiivinen seuraaminen ja muistiinpanojen tekeminen on kaikissa tapauksissa suositeltavaa. Luentojen ei lähtökohtaisesti ole tarkoitus olla monologeja, vaan niiden aikana tulisi myös tarjoutua tilaisuuksia kysymyksille ja keskustelulle. 


\section{Vinkkejä opiskelijalle:}

- Jotta saisit luennoista eniten irti, on muistiinpanoihin hyvä palata luennon jälkeen. Muistiinpanotekniikkaa kannattaa kehittää! Voisi olla myös hyödyllistä pohtia tai lukea etukäteen, mitä asioita luento voisi pitää sisällään.

- Useimmiten luennoitsijoiden esitysten lopussa on koonti lähteistä. Mainittujen lähteiden avulla voit saada lisätietoa aiheesta ja löytää yhteyksiä luennon eri aiheiden välille.

\section{Vinkkejä opettajalle:}

- Flippauksessa eli käänteisoppimisessa (flipped learning) opiskelijoille annetaan etukäteen luennon sisältöihin liittyvää luettavaa tai avainkysymyksiä, jotta luennon aikana heräävä keskustelu olisi oppimisen kannalta laadukkaampaa.

- Online-apuvälineiden avulla voidaan lisätä opiskelijoiden mahdollisuuksia vastata, jakaa ideoita tai kysyä kysymyksiä luentojen aikana.

- Kriittisten kysymysten esittäminen heti luennon alussa voi auttaa opiskelijoita keskittymään ja osallistumaan.

\section{Kieleen ja kulttuuriin liittyviä huomioita:}

Flippausta hyödyntämällä voidaan antaa opiskelijoille mahdollisuus tutustua

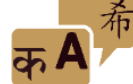
avainkäsitteisiin ennen luentoa. Opiskelijoita, joilla on monikielisiä resursseja, voi rohkaista tutkimaan, miten samat asiat käsitteellistetään eri kielillä, ja pohtimaan kriittisesti, millaisia erilaisia näkökulmia käsitteet välittävät. On hyvä käydä ryhmän kanssa läpi, miten luennolla on tapana keskeyttää tai kysyä kysymyksiä.

\section{Luentopäiväkirja}

Luentopäiväkirjassa kerrotaan kurssin sisällöistä ja kuvataan ja reflektoidaan omaa oppimista kurssin aikana. Luentopäiväkirja tehostaa kurssin aiheiden omaksumista ja ymmärtämistä, koska kirjoittaminen vaatii asioiden huolellista ajattelua. Luentopäiväkirjoilla ja oppimispäiväkirjoilla tarkoitetaan joskus samaa asiaa. Em. tekstejä voidaan kirjoittaa joko opiskelijoiden henkilökohtaiseen käyttöön tai (osittain tai kokonaan) opettajalle/vertaisryhmälle jaettavaksi.

\section{Vinkkejä opiskelijalle:}

- Luentopäiväkirja tarjoaa hyvän tilan tutkia ideoita vapaasti ja nostaa esiin kysymyksiä.

- Oppimispäiväkirjaa kannattaa kirjoittaa vapaalla tyylillä säännöllisesti koko kurssin ajan. Tekstiä voi editoida myöhemmin, mikäli se on tarkoitus jakaa muiden luettavaksi. Lisäksi oppimispäiväkirja tarjoaa hyvän alkupisteen myös muiden tehtävien kirjoittamiselle. 


\section{Vinkkejä opettajalle:}

- Tehtävänannon yhteydessä on hyvä antaa myös kirjoituksen muotoa ja tyyliä koskevia ohjeita.

- On tärkeää ohjeistaa selvästi, mitkä osat ovat henkilökohtaiseen käyttöön ja mitkä osat (vai koko teksti) jaetaan muiden luettavaksi. On myös tärkeää mainita, onko luentopäiväkirja pakollinen osa kurssin suoritusta ja arvioidaanko se.

\section{Kieleen ja kulttuuriin liittyviä huomioita:}

Luentopäiväkirjat voivat antaa opiskelijalle mahdollisuuden hyödyntää eri kieliä oman oppimisensa resursseina. He voivat esimerkiksi kirjoittaa eri kielillä pelkäämättä arviointia tai ajatella kurssin sisältöjä eri kielten kautta. Osa opiskelijoista voi kokea epävarmuutta kirjoittaessaan vapaasti, ja erityisesti jakaessaan vapaasti kirjoittamiaan tekstejä. Tekstin tarkoituksen avaaminen on siksi erityisen tärkeää.

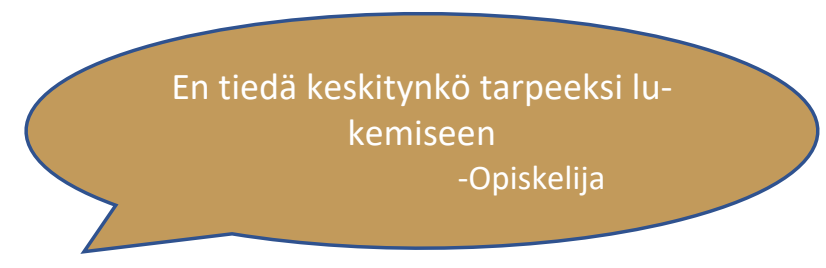

\section{Lukemistehtävät}

Lukeminen on keskeinen osa akateemista opiskelua. Akateemisten tekstien lukeminen vaatii lukijalta taitoa navigoida tekstin eri osien välillä ja tarkastella sisältöjä kriittisesti. Vaikka asiasanat ja tiivistelmä antavat kokonaiskuvan tekstin keskeisimmästä sisällöstä ja viestistä, muut osat palvelevat toisenlaisia tarkoitusperiä. Lukijana on tärkeää osata havaita pääasiat ja kirjoittajan rakentama argumentti sekä kirjoittajan käyttämä näkökulma. Lukemistehtävässä voidaan vaatia tekstin sisällön yhteenvetoa, eri tekstien vertailua ja vastakkainasettelua tai tekstin kriittistä tarkastelua. Lukemistehtävän tavoitteena on kuitenkin rohkaista opiskelijoita perehtymään opiskeltavan asian keskeisimpään kirjallisuuteen.

\section{Vinkkejä opiskelijalle:}

- Pyri lukemaan kurssin kirjallisuutta säännöllisesti koko kurssin ajan, sillä lukemisesta kannattaa tehdä tottumus. Tee hyviä muistiinpanoja ja yritä löytää yhteyksiä kaikesta lukemastasi.

- Lukemistehtävät tarjoavat hyvää pohjaa opetustilanteessa käytävälle keskustelulle ja kurssin kirjallisille tehtäville. 


\section{Vinkkejä opettajalle:}

- Muodosta itsellesi kokonaiskuva kirjallisuudesta, jota opiskelijat lukevat eri kursseille ja rohkaise myös opiskelijoita rakentamaan yhteyksiä eri kurssien ja eri tehtävien välille.

- Opiskelijoita kannattaa rohkaista hyödyntämään lukemisen tukena erilaisia lukemisstrategioita (sisällön ennakointi, muistiinpanojen tekeminen, kysymysten kysyminen, käsitysten jakaminen ja vertailu).

- Opiskelijoita on hyvä vaatia keskustelemaan ja tekemään ryhmätöitä luetun kirjallisuuden perusteella. On myös hyvä antaa opiskelijoiden verrata lukemaansa omiin ajatuksiinsa ja kokemuksiinsa.

\section{Kieleen ja kulttuuriin liittyviä huomioita:}

Lukemisen ennakointii- ja jälkistrategioista (esim. pääkäsitteiden tunnistaminen ja ymmärtäminen, teeman kartoittaminen eri modaliteettien avulla) muistuttaminen voi auttaa opiskelijoita lukemaan tehokkaammin. Monikielisissä ryhmissä voidaan etsiä oleellista lähdekirjallisuutta eri kielillä, mikäli osallistujat osaavat valita päteviä lähteitä. Osalle opiskelijoista arvostettujen kirjoitusten kriittinen tarkastelu voi olla haasteellista, ja siksi erilaisten lukemis- ja kirjoittamistyylien harjoitteleminen voi auttaa opiskelijoita kirjoittamaan omin sanoin lähteiden perusteella.

\section{Luova kirjoittaminen}

Luovassa kirjoittamisessa kielellä ja sanoilla luodaan taideteoksia. Akateemisissa opinnoissa luovan kirjoittamisen tehtävät voivat vaihdella oppimispäiväkirjoista ja henkilökohtaisista tarinoista nopeisiin raapusteluihin, listoihin ja blogeihin. Tekstit voivat käsitellä oppimiskokemuksia, henkilökohtaista elämää, identiteettiä tai esimerkiksi arvoja. Tutkimuksen mukaan elämäkerrallinen kirjoittaminen on erityisen tehokasta henkilökohtaisen ja ammatillisen kasvun kannalta, ja sillä on positiivisia vaikutuksia hyvinvoinnille. Luovaa kirjoittamista voidaan käyttää työskentelymenetelmänä kurssin alussa, kurssin aikana tai kurssin lopussa. Kurssin alussa luovaa kirjoittamista voidaan hyödyntää keskeisiin teemoihin johdattelussa sekä opiskelijoiden omien tavoitteiden ja odotusten asettamisessa (esim. listat, vapaa kirjoitus). Kurssin aikana luova kirjoittaminen voi olla reflektiivinen tehtävä (esim. kirjeet, lyhyet runot). Kurssin lopussa kirjoitustehtävä voi taas olla esimerkiksi lyhyt tarina, jossa kerrotaan henkilökohtaisista, kurssin sisältöihin liittyvistä kokemuksista. Luovalla kirjoittamisella voidaan lisätä opiskeluun leikkisyyttä, iloa ja flowkokemuksia. 


\section{Vinkkejä opiskelijalle:}

- Keskity lopputuloksen sijaan prosessiin: luovassa kirjoittamisessa voit unohtaa akateemisen kirjoittamisen tiukat raamit ja leikkiä sanoilla!

- Älä murehdi virheitä, äläkä anna tyhjän paperin kauhun pysäyttää itseäsi. Tärkeintä on päästä alkuun ja antaa mennä - tekstin hiomisen voit jättää myöhemmäksi. Ensimmäinen versio on harvoin täydellinen ja voit aina muokata tekstiäsi myöhemmin.

\section{Vinkkejä opettajalle:}

- Luovan kirjoittamisen työtapojen hyödyntäminen opetuksessa voi olla hyvä keino innostaa ja tukea opiskelijoiden luovuutta. Vaihtoehtoja on useita runoista ja novelleista mielikuvituksellisiin dialogeihin ja vapaaseen kirjoittamiseen (ajatuksen virta).

- Luovan kirjoittamisen menetelmää hyödynnettäessä on hyvä muistaa, että oppimisen kannalta merkityksellisintä on kirjoittamisprosessi, ei lopputulos tai täydellinen kieliasu.

- Opiskelijoille kannattaa tarjota työskentelyn tueksi jonkinlaisia runkoja, jotta he pääsevät alkuun, mutta jättää myös riittävästi tilaa inspiraatiolle.

- Oppiminen on tehokkaampaa, kun luovan kirjoittamisen prosessi sisältää myös sosiaalisia elementtejä, kuten vertaiskeskustelua, tarinoiden jakamista jne.

\section{Kieleen ja kulttuuriin liittyviä huomioita:}

Luova kirjoittaminen voi tarjota arvokkaan tilaisuuden kokeilla erilaisia ääniä ja

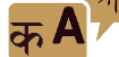
tutkia ideoita omien luovien tuotosten kautta. Luova kirjoittaminen on hyvä tilaisuus kielellä leikittelylle, ja tekstiin voi upottaa myös useita eri kieliä. Osallistujia voi joutua muistuttamaan, että prosessi auttaa oppimisessa ja kehityksessä. Taustoista kirjoittaminen, henkilökohtaisten tarinoiden jakaminen ja niistä keskusteleminen sekä ilon hetkien löytäminen kielellä leikittelyn kautta voi tuoda uusia oivalluksia jokaiselle opiskelijalle - ja auttaa samalla ylittämään kulttuurisia rajoja.

\section{Muistiinpanojen tekeminen 1}

Muistiinpanojen tekemisellä voidaan tarkoittaa pääkohtien poimimista kirjallisuudesta ja luennoilta tai pääkohtien kirjoittamista uudelleen omin sanoin. Muistiinpanojen tekemisessä voidaan käyttää erilaisia lähestymistapoja. Osa opiskelijoista hyödyntää digitaalisia apuvälineitä, kun taas osa hyötyy enemmän käsin kirjoittamisesta tai vaikka kuvien piirtämisestä. Muistiinpanoihin kannattaa sisällyttää kriittisiä huomioita, kysymyksiä ja erilaisia näkökulmia kurssin sisältöihin. Systemaattisen lähestymistavan kehittäminen akateemisten opintojen aikana prosessoitavaan valtavaan tietomäärään on tärkeä osa opiskeluprosessia. 


\section{Vinkkejä opiskelijalle:}

- Kokeile erilaisia tapoja tehdä muistiinpanoja, jotta löydät itseäsi parhaiten palvelevan tekniikan. Oman systeemin kehittäminen voi viedä aikaa, mutta pitkässä juoksussa siitä on paljon hyötyä

\section{Vinkkejä opettajalle:}

- Opiskelijoita on hyvä rohkaista tarttumaan opiskelumateriaaleihin erilaisin keinoin, eikä vain omaan muistiin tai puhelimen kameraan tukeutuen.

\section{Kieleen ja kulttuuriin liittyviä huomioita:}

Muistiinpanoja tehdessä voidaan hyödyntää eri kieliä. On hyvä pohtia, mikä on

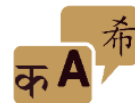
työskentelyn tavoitteena ja mikä kieli tukee opiskelua parhaiten. Opiskelijat tottuvat usein käyttämään tiettyä muistiinpano tekniikkaa, ja se voi ajan myötä alkaa vaikuttaa myös ainoalta tavalta. Siksi on silloin tällöin hyvä tutkia erilaisia tekniikoita, jotta voidaan varmistaa, että opiskelijat kehittävät juuri heitä itseään parhaiten hyödyttäviä opiskelutapoja.

\section{Opetus/Kontaktiopetus}

Useimmat kurssit sisältävät luentoja ja/tai työpajoja, seminaareja ja/tai lukupiirejä, joista käytetään kokoavasti termiä opetus tai kontaktiopetus. Ryhmäopetus tapahtuu pienemmissä, noin 20 opiskelijan ryhmissä. Joskus kontaktiopetusta voi edeltää ennakoiva lukemistehtävä, jonka avulla opiskelijat valmistautuvat kontaktiopetuksessa käytäviin keskusteluihin. Koska keskustelut ovat kontaktiopetuksessa suuressa roolissa, opiskelijoilta edellytetään läsnäoloa.

\section{Vinkkejä opiskelijalle:}

- On hyvä muistaa, että kontaktiopetuksen tuntimäärä on vain pieni osa koko kurssin suorittamiseen vaadittavasta työtuntien määrästä.

- Kun valmistaudut opetukseen, kannattaa myös miettiä, mitä kysymyksiä haluaisit kysyä ja millaista tietoa ja osaamista haluaisit kurssin avulla saada.

\section{Vinkkejä opettajalle:}

- Keskusteluihin osallistumisen kynnys on matalampi, jos keskustelunaihe on opiskelijoiden tiedossa jo etukäteen. Pienissä ryhmissä käydyt keskustelut voivat puolestaan edesauttaa yhteisen keskustelun syntymistä.

- Keskustelussa ilmenevien erilaisten roolien tiedostaminen voi auttaa varmistamaan, että jokainen opiskelija osallistuu keskusteluun jollakin tavalla. 


\section{Kieleen ja kulttuuriin liittyviä huomioita:}

Opetuksessa on hyödyllistä käyttää aikaa kurssin avainkäsitteisiin ja niiden määrittelyyn. Opiskelijoita voi myös kannustaa katsomaan, löytyykö vastaavia käsitteitä muista kielistä ja käsitteellistetäänkö ilmiö samalla tavalla. Osalle opiskelijoista ryhmäkeskustelut voivat olla jännittäviä, varsinkin jos teema tai kieli on vieras, kun taas opiskelijat, jotka ovat tottuneet osallistumaan ryhmäkeskusteluihin, voivat alkaa liiaksi hallita keskustelua. Keskustelujen laatua voi kuitenkin kehittää sopimalla yhteisistä säännöistä, kuten että jokainen osallistuu jossakin keskustelun vaiheessa ja erilaiset näkökannat ovat keskusteluun tervetulleita. Lisäksi opiskelijoiden kannalta voi olla hyödyllistä, jos heille tarjotaan aikaa valmistautua keskusteluun ennen varsinaista opetuskertaa.

\section{Oppimispäiväkirja 1}

Oppimispäiväkirja on kirjoitettua itsereflektiota kurssin aikana tapahtuneesta oppimisesta. Oppimispäiväkirja sisältää koonnin kurssin sisällöistä, mutta myös opiskelijan omasta, kehittyvästä ymmärryksestä suhteessa kurssin sisältöihin (luennot, kirjallisuus, keskustelut). Oppimispäiväkirjassa tulisikin olla myös opiskelijan omia näkökulmia, ideoita, kysymyksiä, pohdintoja ja käsityksiä. Ajan myötä näiden näkökulmien tulisi näkyä päiväkirjassa enenevissä määrin, ja niiden tulisi sisältää käsiteltyjen ilmiöiden kriittistä pohdintaa. Oppimispäiväkirja vastaa laajuudeltaan esseetä. Joissain tapauksissa oppimispäiväkirja voi olla osa kurssin kokonaissuoritusta. Kurssikohtaiset ohjeet annetaan kurssin alussa. Alla olevan linkin takaa löytyvä oppimispäiväkirjan mallipohja on hyvä ottaa alkuvaiheessa kirjoittamisen tueksi. https://studysites.sagepub.com/burnsandsinfield3e/study/Chapter\%2023/Reflective\%20learning\%20diary\%20template.pdf

\section{Vinkkejä opiskelijalle:}

- Aloita oppimispäiväkirjan kirjoittaminen heti ensimmäisen opetuskerran jälkeen. Kurssin materiaalit ja luentomuistiinpanot muodostavat vain osan oppimispäiväkirjasta. Omat ajatuksesi, kriittiset analyysit, havainnot ja argumentit ovat myös tärkeää sisältöä!

- Akateemisen lisämateriaalin lukeminen voi antaa lisäideoita oppimispäiväkirjan kirjoittamiseen. Myös oppimispäiväkirjan nimeäminen voi auttaa näkökulman kehittelyssä.

- Oppimispäiväkirja tarjoaa mahdollisuuden havainnoida ja arvioida omaa oppimisprosessia sekä analysoida omaa oppimista. Oppimispäiväkirjaan kannattaakin aika ajoin palata, jotta huomaat, miten omat ideasi ovat kehittyneet kurssin ja kirjoitusprosessin aikana. 


\section{Vinkkejä opettajalle:}

- Hyvä oppimispäiväkirja sisältää reflektiota opiskelijan omasta ajattelusta ja oppimisprosessista. Parhaimmillaan se on opiskelijan ja kurssin sisältöjen välisen dialogin "lopputuote".

- Opiskelijoita auttaa, jos oppimispäiväkirjan tarkoitus avataan sanallisesti. Myös arviointiperusteet on hyvä olla heti saatavilla, mikäli niitä hyödynnetään oppimispäiväkirjan arvioinnissa.

- Viimeistelemättömien ja henkilökohtaisten, kurssin teemoihin liittyvien ajatusten esittäminen saattaa olla osalle opiskelijoista haastavaa. Kynnystä voi madaltaa pyytämällä opiskelijoita esittelemään lyhyitä otteita oppimispäiväkirjoistaan.

\section{Kieleen ja kulttuuriin liittyviä huomioita:}

Oppimispäiväkirja voi olla osalle opiskelijoista täysin uudenlainen akateeminen tehtävä. Parhaimmillaan oppimispäiväkirja auttaa kehittämään itseymmärrystä ja laajentamaan ajattelua ja perspektiiviä myös kulttuurienvälisessä kontekstissa. Lyhyiden otteiden reflektointi auttaa opiskelijoita ymmärtämään omia ajatuksiaan, arvojaan ja tunteitaan, ja tunnistamaan omia vahvuuksiaan sekä kehittämisen kohteitaan. Otteiden jakaminen auttaa opiskelijoita myös tunnistamaan, miten jokainen kirjoittaa, ajattelee ja yhdistelee oppimistaan ainutlaatuisella tavalla, ja luo sitä kautta tilaa uudenlaisille tavoille käyttää eri kieliä.

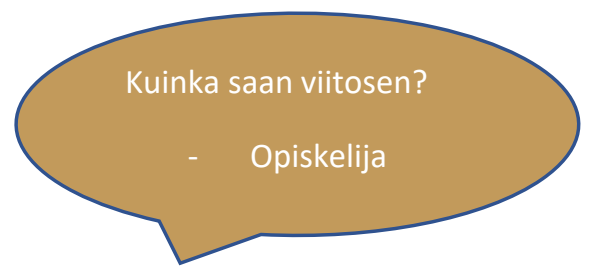

\section{Oppimistehtävät: oppimispäiväkirjat, esseet, lukemistehtävät,}

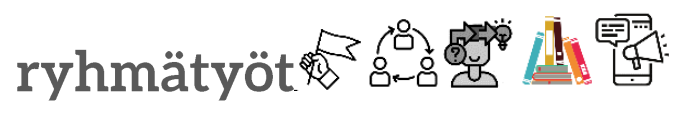

Oppimistehtävät ovat merkittävä osa kurssien suoritusta ja arviointia. Osalla kursseista arviointi voi perustua yksinomaan oppimistehtäviin. Oppimistehtävät voivat olla yksilö-, pari- tai ryhmätehtäviä. Kaikki tehtävät vaativat huolellista suunnittelua sekä ajallista panostusta, ja niissä tulisi hyödyntää kurssin materiaalia ja muuta työskentelyä. Tämä opas tarjoaa kuvauksia monista erilaisista opiskelumuodoista, mutta lisäohjeita ja tarkennuksia voi aina kysyä myös kurssin opettajalta tai luennoitsijalta.

\section{Vinkkejä opiskelijalle:}

- Oppimistehtävien tulisi tukea oppimis- ja opiskeluprosessiasi. Kun selvität itsellesi tehtävän tavoitteen, hyödyt siitä enemmän! 
- Arvointikriteereihin tutustuminen auttaa oppimistehtävän suunnittelussa.

- Suunnittele aikataulusi huolella! Huolellinen suunnittelu auttaa eri kurssien tehtävien ja aikataulujen yhteensovittamisessa.

- Katso lisävinkkejä ryhmässä työskentelyyn Ryhmätyöskentely-osiosta.

\section{Vinkkejä opettajalle:}

- Tehtävänanto, joka on opettajan mielestä selkeä, ei välttämättä ole sitä opiskelijalle. Olisikin hyvä varmistaa, että opiskelijat ovat ymmärtäneet, mitä tehtävä pitää sisällään. Lisäksi myös kontaktiopetuskerroilla olisi hyvä varata aikaa itsenäisen tehtävän alustavalle suunnittelulle.

- Jos itsenäisesti hoidettavia ryhmätehtäviä on liikaa, opiskelijoille voi olla haasteellista täyttää kaikkia kurssin vaatimuksia.

\section{Kieleen ja kulttuuriin liittyviä huomioita:}

Tehtäviä saadaan harvoin valmiiksi yhdeltä istumalta. Onkin hyvä pohtia, millaisia

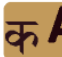
erilaisia vaiheita tehtävän tekeminen vaatii, ja miten prosessia voisi tukea erilaisten työtapojen avulla. Esimerkiksi visualisoinnit, ajatuskartat ja eri kielillä ajatteleminen voivat viedä työskentelyprosessia eteenpäin.

\section{Osallistuminen 1 10 肠}

Osallistuminen on akateemisen opiskelun avainsana, ja sitä käytetään usein arvioinnin perustana. Osallistuminen tarkoittaa lyhykäisyydessään sitä, että opiskelija sitoutuu aktiivisesti opiskeltavaan aiheeseen ja opiskeluprosessiin. Osallistuminen voi siis tapahtua monessa eri muodossa, ja samalla kun osallistuminen tukee yksittäisen opiskelijan kehitystä, se voi myös tukea vertaisoppimista ja yhteisöllisen ajatteluprosessin rakentumista. Aktiivinen osallistuminen auttaa lisäämään oppimisympäristön vuorovaikutuksellisuutta.

\section{Vinkkejä opiskelijalle:}

- Etsi sellainen osallistumisen keino, mikä sopii juuri sinulle. Se voi olla akateemisen artikkelin kommentointia tai keskustelun sisältöihin liittyvien kysymysten esittämistä tai se voi olla omakohtaisten opiskelu- tai työkokemusten jakamista, ja sitä kautta uusien ideoiden ja ajatusten herättelyä.

- Valmistaudu kontaktiopetukseen lukemalla kirjallisuutta ja miettimällä valmiiksi mitä haluaisit nostaa siitä yhteiseen keskusteluun.

- Ideaalitilanteessa voit osallistumisellasi osoittaa korkeamman tason ajattelua, joka on enemmän kuin vain materiaalin lukemista ja toistamista. Näin voit tuoda oman panoksesi koko yhteisön kriittisen ajattelun prosessiin. 


\section{Vinkkejä opettajalle:}

- Opiskelijat hyötyvät siitä, että moninaiset osallistumisen muodot otetaan opetuksessa huomioon. Kurssi on hyvä suunnitella niin, että pedagogisissa ideoissa tuetaan aktiivista osallistumista (esim. parityöskentely, lukupiirit, opitun jakaminen, yhteiselle keskustelualustalle kirjoittaminen opetuksen aikana jne.)

- Mikäli osallistuminen on osa loppuarviointia, on tärkeää pohtia erilaisia keinoja, joilla opiskelijat voivat osallistua työskentelyyn (kontaktiopetuksessa tai verkossa, yksilönä tai ryhmissä, puhuttujen, kirjoitettujen tai soveltavien tehtävien muodossa) ja mitkä taas voivat olla osallistumisen haasteita.

\section{Kieleen ja kulttuuriin liittyviä huomioita:}

Opiskelijoita on hyvä rohkaista hyödyntämään monipuolisesti kaikkia resursse-

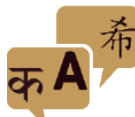
jaan opiskeluun ja opetukseen osallistuessaan. Opiskelijoita voi esimerkiksi rohkaista pohtimaan kriittisesti, kuinka eri kieliä voi hyödyntää opiskelussa (esim. kirjoittaminen ja ajatuskartat) ja kehittämään erilaisia kommunikaation kanavia, sekä jakamaan kokemuksiaan ja ymmärrystään eri näkökulmista. Opiskelijoita voi myös rohkaista kysymään asioita toisiltaan ja rakentamaan ymmärrystään yhdessä. Varmistamalla, että jokainen opiskelija ymmärtää kurssin keskeiset käsitteet ja tavoitteet, voidaan auttaa opiskelijoita keskittymään työskentelyyn ja rohkaista heitä pohtimaan, miten he itse voisivat siihen osallistua.

\section{Palaute (vertais- tai ryhmäpalaute)}

Palaute on tärkeä osa oppimisprosessia, ja sen pitäisi olla hyödyllistä sekä palautteen antajalle että vastaanottajalle. Palaute sekoitetaan usein arviointiin. Palautetta annetaan kuitenkin useimmiten jo oppimisprosessin aikana, jolloin se perustuu käynnissä olevaan työskentelyyn. Palautetta kannattaa antaa eri näkökulmista, ja opiskelijat voivat myös itse ehdottaa, millainen palaute heitä hyödyttäisi eniten. Palautteen yhdistäminen käynnissä olevaan opiskeluprosessin vaiheeseen on tärkeää. Jos opiskelija on esimerkiksi aloittamassa esseen idean kehittelyä, palaute voi auttaa idean valinnassa ja jatkokehittelyssä. Mikäli taas essee on jo lähes valmis, kriittinen palaute voi auttaa huomaamaan ja korjaamaan tekstissä olevia epäselvyyksiä tai hämmentäviä kohtia.

\section{Vinkkejä opiskelijalle:}

- Kun kommentoit toisen työtä, kiinnitä huomiota sekä työn vahvuuksiin että heikkouksiin, ja anna myös muutosehdotuksia.

- Yritä olla ystävällinen mutta myös selkeä. Hampurilaismallin mukaan toimiminen on hyvä tapa antaa palautetta: aloita hyvistä puolista, kommentoi sitten heikkouksia antaen samalla kehitysehdotuksia ja päätä palaute positiiviseen kommenttiin. 
- Ideaalitilanteessa palaute auttaa katsomaan omaa työtä ulkopuolisen silmin ja työstämään sitä eteenpäin.

\section{Vinkkejä opettajalle:}

- Palautteen antamisen ja saamisen tulisi olla merkittävä osa opiskeluprosessia, sillä se auttaa opiskelijoita etenemään kohti kurssin tavoitteita ja ymmärtämään paremmin omaa kehitystään.

- Selkeät kriteerit auttavat opiskelijoita palautteen antamisen ja vastaanottamisen harjoittelemisessa. Ne myös auttavat suuntaamaan huomion olennaisiin asioihin.

- Palautteen annon yhteydessä olisi myös hyvä mainita, että jokainen opiskelija voi itse päättää, miten haluaa hyödyntää saamaansa palautetta.

- Palautteen antamisessa voidaan hyödyntää apuvälineenä Turnitin-ohjelmaa.

\section{Kieleen ja kulttuuriin liittyviä huomioita:}

Kriittisen vertaispalautteen saaminen ei aina ole helppoa, vaikkakin sen kuuntele-

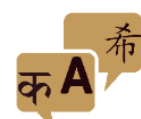
minen ja siihen vastaaminen rakentavalla tavalla ovat elintärkeitä taitoja niin korkeakoulutuksessa kuin tulevaisuuden työpaikoilla. Kriteerien käyttäminen tai niiden kehittäminen yhdessä opiskelijoiden kanssa voi helpottaa palautteen antamista ja vastaanottamista. Työskenneltäessä monikulttuurisen ryhmän kanssa palautteen antamisen ja vastaanottamisen mallintaminen voi olla hyvä idea.

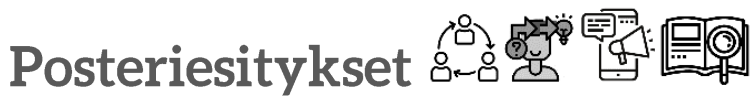

Posteriesityksessä käsitellään tiiviillä, visuaalisella tavalla tiettyyn aiheeseen liittyvää tutkimusta ja/tai ymmärrystä. Visuaalisessa esityksessä tulisi välittyä posterin eli julisteen ydinajatus, jota voidaan laajentaa lyhyellä suullisella selityksellä. Posterit ovat hyödyllisiä välineitä käsitteiden, avainlöydösten, aiheiden välisten yhteyksien sekä kriittisten kysymysten visualisoinnissa. Esittelijän täytyy pohtia luovalla tavalla sekä esityksen tarkoitusta että välitettävää viestiä. Alla olevastä linkistä löytyy ohjeet JYU:n posterimallin käyttöön: https://uno.jyu.fi/en/help-centre/communications-and-public-relations/presentation-materials/poster

\section{Vinkkejä opiskelijalle:}

- Posteriesitys tarjoaa luovan ja joustavan tavan esitellä omaa tutkimusta ja/tai ymmärrystä.

- Yleisön tulisi pystyä ymmärtämään posterin viesti ilman suullista selitystä, joskin sillä voidaan lisätä esitykseen yksityiskohtia.

- Valmiit mallit voivat auttaa tasapainottamaan tekstin ja visuaalisten elementtienmäärää. Älä tee posteristasi liian täyttä. Käytä luovuutta ja kokeile erilaisia ideoita maksimoidaksesi posterisi tehokkuuden. 


\section{Vinkkejä opettajalle:}

- Posteriesityksen tarkoituksen ymmärtäminen auttaa opiskelijaa suunnittelemaan ja kehittämään omaa tuotosta.

- Ennen oman posterityöskentelyn aloittamista erilaisten esimerkkipostereiden ja mallien yhteinen tarkastelu voisi olla opiskelijoille hyödyllistä.

- Posteriesityksen arviointikriteerien tulisi ulottua muuhunkin kuin posterin designiin tai sisällön selkeyteen.

\section{Kieleen ja kulttuuriin liittyviä huomioita:}

Posteriesityksiin voidaan sisällyttää luovasti monia työskentelykieliä ja siten edesauttaa monikielistä vuorovaikutusta. Perinteisten kysymys-vastausmallisten posteriesitysten sijaan dialogisuutta voidaan synnyttää sijoittamalla Post-it -lappuja ja kyniä posterin viereen, ja siten rohkaista yleisöä kirjoittamaan ylös posteriin liittyviä kysymyksiä tai kommentteja. Samalla myös esittäjä saa hyödyllistä palautetta.

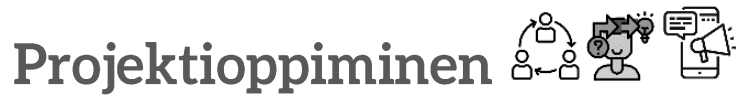

Projektioppiminen perustuu autenttiseen kysymykseen tai ongelmaan, joka toimii lähtökohtana työskentelylle. Projektioppimisessa yhdistyvät poikkitieteellisyys sekä monimuotoisten oppimisyhteisöjen ja -ympäristöjen tarpeet. Projektia ohjaavan kysymyksen vastaus voidaan esittää erilaisissa muodoissa (esim. mallit, raportit, videot, ohjelmat, näytelmät), joita voidaan yhdessä tarkastella ja arvioida kriittisesti.

\section{Vinkkejä opiskelijalle:}

- Hyvän kysymyksen löytäminen ja muotoileminen vie aikaa, mutta se on tärkeä osa oppimisprosessia.

- Kannattaa pohtia tarkkaan, millaisia erilaisia mahdollisuuksia saman kysymyksen lähestymiseen voi olla, ja miten samaa ongelmaa käsitellään eri lähteissä.

\section{Vinkkejä opettajalle:}

- Kun opiskelijat muodostavat omia ideoitaan, on hyvä tarjota myös malleja, millainen hyvä tutkimuskysymys voisi olla (esim, millainen museonäyttely tukee kestävän kehityksen opiskelua peruskoulussa)

- Koska projektioppimisessa yhdistetään monia eri opiskelun muotoja, myös lopputuotokset voivat olla hyvin monenlaisia.

\section{Kieleen ja kulttuuriin liittyviä huomioita:}

Projektioppiminen tarjoaa mahdollisuuden joustavaan, yhteistoiminnalliseen op-

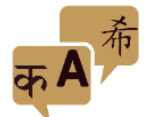
pimiseen. Joillekin opiskelijoille käytännönläheinen oppimisen tapa voi olla vieras ja se voi 
tuntua epäakateemiselta. Projektioppiminen mahdollistaa yhteyksien luomisen akateemisen ympäristön ulkopuolelle. Se voi myös mahdollistaa kielellisten ja kulttuuristen resurssien hyödyntämisen oppimisessa ja opitun jakamisessa.

\section{Reflektiiviset luonnosvihkot (ks. myös osat Reflektio ja Visuaa-}

\section{liset työkalut) $\%$ 새}

Reflektiivisiä luonnosvihkoja voidaan käyttää oppimispäiväkirjoina ja/tai tehtävinä, joiden tarkoitus on rohkaista opiskelijoita työstämään uusia ideoita ja akateemista sisältöä reflektiivisellä ja luovalla tavalla. Reflektiiviset luonnosvihkot ovat hyvä tapa dokumentoida ajatteluprosessia (kysymyksiä, ideoita ja oivalluksia) sekä tarjota tilaa uusien ideoiden kritisoinnille ja monipuoliselle tarkastelulle.

\section{Vinkkejä opiskelijalle:}

- Saatat yllättyä reflektiivisen luonnosvihkon leikkisyydestä ja luovuudesta verrattuna perinteiseen akateemiseen opiskelukulttuuriin. Luonnosvihkolla leikittely voi kuitenkin auttaa lähestymään uusia ideoita eri tavoin ja siten kehittämään myös omia akateemisia pohdintoja.

\section{Vinkkejä opettajalle:}

- Teemojen kehittely voi rohkaista itsenäiseen ajatteluun.

- Reflektiivisen luonnosvihkon arviointi ei ole suositeltavaa, sillä se voi rajoittaa kriittistä ja luovaa ajattelua. Luonnosvihkoja voidaan kuitenkin käyttää opiskelijoiden aktiivisen osallistumisen varmistamiseksi, ja niiden avulla voidaan päästä jyvälle opiskelijan ajattelun kehittymisestä.

- Reflektiivisiä luonnosvihkoja voidaan käyttää johonkin teemaan liittyvän yksilöllisen ja yhteisöllisenreflektion apuvälineenä.

\section{Kieleen ja kulttuuriin liittyviä huomioita:}

Reflektiivisten luonnosvihkojen avulla voidaan vähentää akateemisen, muodollisen kielenkäytön painetta, ja silti tarjota arvokas tila oman ajattelun kehittämiselle sekä lähteiden ja kokemusten monipuoliselle hyödyntämiselle. Astuminen pois akateemisista perinteistä voi olla osalle opiskelijoista haasteellista ja hämmentävää, kun taas osalle eri modaliteettien hyödyntäminen voi olla vapauttavaa ja siten inspiroida uudenlaiseen ajatteluun ja sitouttaa akateemiseen sisältöön. 


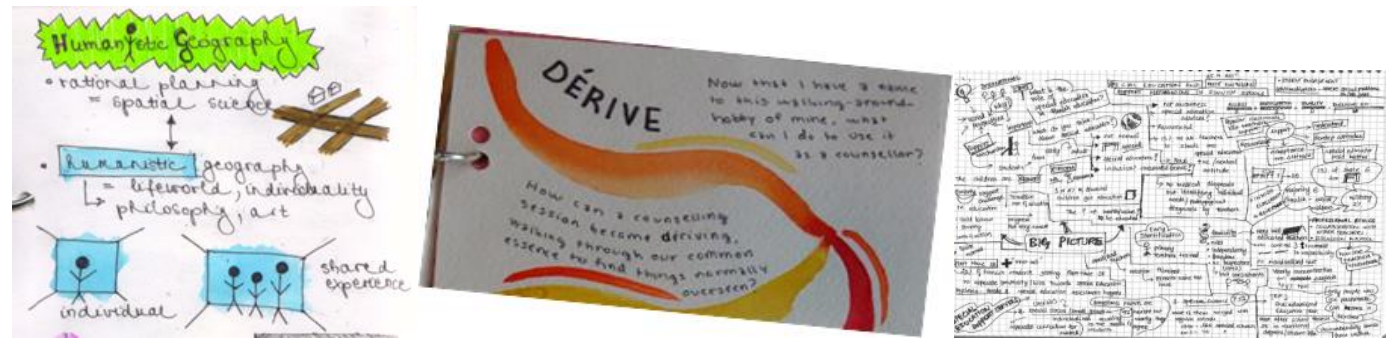

Kuva 3. Reflektiivisiä luonnossivuja (Josephine Moate

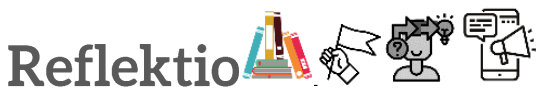

Reflektio on tärkeä osa kriittistä ajattelua, ja se on myös tärkeässä roolissa teorian ja käytännön yhdistämisessä. Reflektio auttaa syventämään ymmärrystä, ja tunnistamaan sen muodostumisen kompleksisuutta (esim. omien perustavien oletusten tunnistaminen, uusien yhteyksien luominen). Reflektiivisen asenteen kehittyminen vaatii harjoitusta.

\section{Vinkkejä opiskelijalle:}

- Vaikka omien käsitysten reflektointi voi olla aluksi haasteellista, on se kuitenkin taito, jota on tärkeää kehittää yliopisto-opintojen aikana.

- Reflektointi yhdessä toisten kanssa niin muodollisessa kuin epämuodollisessa tilanteessa synnyttää rikasta keskustelua. Toisten kuunteleminen ja kysymysten kysyminen auttaa kehittämään yksilön ja ryhmän metakognitiivisia taitoja.

- Reflektoimalla omia opintoja ja edistymistä koko oppimisprosessista tulee merkityksellisempi. Omien oppimistavoitteiden asettaminen auttaa fokusoimaanomaa reflektiota, ja on myös hyvä tapa seurata omaa kehitystä.

\section{Vinkkejä opettajalle:}

- Kuten muutkin taidot myös hyvien reflektiotaitojen kehittyminen vaatii ohjausta. Reflektiota ohjaavien kysymysten esittäminen ja oman reflektion jakaminen auttavat opiskelijoita pääsemään jyvälle reflektioprosessista.

\section{Kieleen ja kulttuuriin liittyviä huomioita:}

Koska reflektointi on henkilökohtainen prosessi, opiskelijat hyötyvät oppimisym-

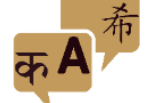
päristöstä, joka tarjoaa tarpeeksi aikaa ajattelulle, ajatusten jakamiselle ja kommentoinnille. Reflektioiden yhteinen jakaminen tarjoaa osallistujille erilaisia näkökulmia ja oivalluksia siitä, miten eri tavoin eri opiskelijat käsittelevät saman kurssin materiaaleja ja kokemuksia. On hyvä huomioida, että opiskelijat eivät välttämättä ole tottuneita reflektoimaan ajatuksiaan julkisesti oppimistilanteessa. Opiskelijoille voi olla yllätys, että he voivat hyödyntää reflektioprosessissa eri kieliä. Monikieliset opiskelijat kuitenkin hyötyvät siitä, että heillä 
on mahdollisuus käyttää eri kieliä ideoiden tutkimisessa ja oman oppimisen ja ajattelun reflektoinnissa.

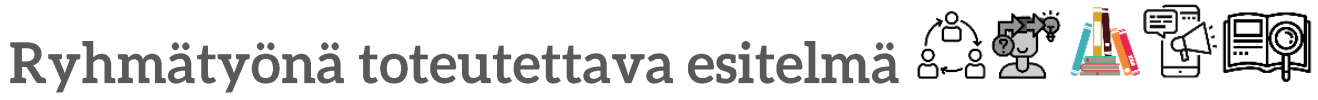

Ryhmätyönä toteutettava esitelmä on yhteistyöllä tuotettu esitys, jossa on hyödynnetty jokaisen ryhmän jäsenen vahvuuksia ja yhdessä ajattelua. Esitelmän sisältö riippuu ohjeistuksesta, mutta ryhmätyönä toteutettava esitelmä tarjoaa hyviä mahdollisuuksia tutkia teemaa eri näkökulmista ja lopulta esittää tiivistetysti se ymmärrys, mikä ryhmälle on prosessin aikana syntynyt.

\section{Vinkkejä opiskelijalle:}

- Varmistakaa, että jokainen ryhmän jäsen ymmärtää tehtävän tavoitteen. Käyttäkää ryhmänä aikaa siihen, että valitsette, miten tavoite voidaan saavuttaa hyödyntämällä ryhmän erilaisia resursseja.

- Tiedostakaa myös ryhmän jäsenten erilaiset mieltymykset ja vahvuudet, ja järjestäkää aikataulu, jossa on ilmaistu selkeät tavoitteet toiminnalle.

- Antakaa toisillenne rakentavaa palautetta, ja hyödyntäkää digitaalisia apuvälineitä kommunikaation ja yhteistyön tukena, esim. pitäkää yhteistä lokikirjaa siitä, mitä tulee olla tehtynä, milloinkin ja kuka siitä vastaa.

- On tärkeää, että ryhmän jäsenet pitävät kommunikaatiota yllä koko tehtävän ajan. Jos jokin asia on epäselvä, kysykää. Harjoitelkaa esitelmää yhdessä.

\section{Vinkkejä opettajalle:}

- Selkeät ohjeet koskien tehtävän tavoitetta, aikataulua ja arviointia auttavat opiskelijoita työskentelemään yhdessä ja saavuttamaan tehtävän vaatimukset.

- On hyvä sopia yhteiset säännöt yhteistyölle, kuten kuinka varmistetaan, että kaikki jäsenet osallistuvat työskentelyyn ja kuinka ratkaistaan erimielisyydet.

- Jos osallistujilla on liian vähän aikaa esitelmän laatimiseen, tehtävän laatu kärsii.

\section{Kieleen liittyviä huomioita:}

Ryhmätyönä toteutettavat esitelmät tarjoavat mahdollisuuksia hyödyntää opis-

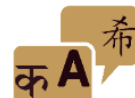
kelijoiden vahvuuksia ja moninaisia kielellisiä repertuaareja. Kaikki jäsenet hyötyvät ideoiden ja ymmärryksen jakamisesta, jos tehtävä ajatellaan oppimisen mahdollisuudeksi, eikä vain jo olemassa olevan tiedon esittämiseksi. Yhteiset säännöt auttavat opiskelijoita pysymään yhdessä varsinkin silloin, kun monikulttuurinen ryhmä työskentelee yhdessä ensimmäistä kertaa. 


\section{Ryhmätyöskentely}

Ryhmätyöskentelyn tulisi edistää opiskelijoiden keskinäistä sekä opiskelijoiden ja opettajan välistä vuorovaikutusta samalla kun perehdytään kurssin sisältöihin. Ideaalitilanteessa ryhmätyö tukee innovatiivisten ideoiden kehittymistä ja vertaisoppimista. Useilla kursseilla ryhmätyöskentelyn lopputuloksena on esitys tai kirjallinen tehtävä, joka on laadittu yhdessä työskennellen ja joka perustuu kirjallisuuteen ja yhdessä käytyihin keskusteluihin. Ryhmätehtävät sisältävät suunnittelua, tiedon hakemista ja jakamista, tekstien kirjoittamista ja editointia sekä työn esittelyä. Jokaiselta opiskelijalta edellytetään osallistumista työskentelyyn, ja koko ryhmän työskentely arvioidaan lopullisen työn perusteella. Työskentelyn jälkeen tehtävällä vertaisarvioinnilla voidaan pohtia, miten ryhmä toimi ja mitä työskentelyllä saavutettiin.

\section{Vinkkejä opiskelijalle:}

- Jakakaa aluksi työtä mielenkiinnon kohteiden ja vahvuuksien mukaan.

- Sopikaa selkeästi, mitä kunkin opiskelijan tulee tehdä ja mihin mennessä. Laatikaa myös yhteinen, ymmärrettävä toimintasuunnitelma.

- Laatikaa aikataulu säännöllisistä ryhmätapaamisista, joissa voitte keskustella siitä mitä on tehty, antaa rakentavaa palautetta toisillenne ja arvioida työskentelyn etenemistä. Jakakaa sitten työtä seuraavaa vaihetta varten.

- Jokaisen jäsenen ei tarvitse olla fyysisesti läsnä jokaisessa tapaamisessa. Hyödyntäkää Skype-, Zoom-, Google Drive- ja Microsoft Teams -ohjelmia.

\section{Vinkkejä opettajalle:}

- Selkeät ohjeet auttavat opiskelijoita ymmärtämään, mitä pitää tehdä ja mitä heiltä odotetaan.

- Yhteiset perussäännöt auttavat opiskelijoita paneutumaan tehtävään. Kannattaa siis käydä yhdessä läpi miten työtä ja tehtäviä jaetaan (mikä asia on kenenkin vastuulla), missä ja miten tietoa jaetaan, kuinka tärkeää on että yhteisiin aikarajoihin sitoudutaan jokaisessa työskentelyn vaiheessajne.

- Yhteisten ryhmätapaamisten järjestäminen voi olla haastavaa, sillä ryhmän jäsenillä on todennäköisesti eri aikataulut.

\section{Kieleen ja kulttuuriin liittyviä huomioita:}

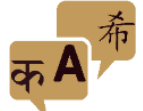

Ryhmätyöskentelyn tulisi tarjota mahdollisuuksia harjoitella vuorovaikutustaitoja turvallisessa ympäristössä. Osallistujat voivat hyötyä siitä, että rooleja ja vastuualueita kierrätetään ryhmän sisällä. On tärkeää huomioida, ettei ryhmätyöskentely välttämättä kuulu kaikkiin koulukulttuureihin ja voi siksi olla toisille vieraampaa. Yhteisten sääntöjen ja aikataulun laatiminen voi auttaa välttämään työtehtävien epätasaista jakautumista ryhmän jäsenten välille. Koska ryhmätyöskentelyssä kerätään ja esitellään ideoita ja informaatiota, se voi 
tarjota ryhmän jäsenille loistavia mahdollisuuksia käyttää moninaisia kielellisiä repertuaarejaan.

\section{Tarinarinki 总}

Tarinankerronta on fasilitoinnin keino, jolla tuetaan luovuutta ja innovatiivisuutta oppimistilanteessa. Tarinaringit alkavat kysymyksellä, joka on toiminnan keskiössä. Osallistujat jakautuvat kolmen hengen ryhmiin, ja jokainen opiskelija ottaa itselleen roolin (esim. Tarinankertoja, Sadonkorjaaja, Todistaja). Tarinankertoja vastaa esitettyyn kysymykseen kertomalla tarinan. Sadonkorjaaja kuuntelee tarkasti tarinan sisältöä, ja Todistaja keskittyy tarkkaileman tarinankertojaa. Tarinan jälkeen Sadonkorjaaja ja Todistaja kertovat havainnoistaan. Rooleja voidaan kierrättää, jotta jokainen osallistuja saa olla tarinankertoja, todistaja ja sadonkorjaaja. Jokainen tarinarinki kestää noin 15 minuuttia, josta kymmenen minuutta on varattu tarinalle ja viisi minuuttia havaintojen jakamiselle. Prosessin kulku on hyvä esittää graafisesti tai kirjoitettuna. Lähde: http://www.globaltfokus.dk/images/Kapacitetsudvikling/indsatser/SOL_ressourcedatabase/1._Toolbox/Guide_Trio_Story_sharing.pdf

\section{Vinkkejä opiskelijalle:}

- Tarinat ovat voimakas keino kehittää ymmärrystä ja laajentaa omia käsityksiä opiskelijaryhmän moninaisuudesta.

- Tämä aktiviteetti sisältää aktiivista ja tavoitteellista kuuntelua sekä kuullun selittämistä uudelleen omin sanoin.

- Tarinan kertomisen ja kuuntelemisen jälkeen piirrä tai kirjoita, millaisia tuntemuksia tai millaista ymmärrystä tarina herätti.

\section{Vinkkejä opettajalle:}

- Tämä aktiviteetti vaatii avointa ja luottamuksellista ilmapiiriä, jossa ihmiset voivat avautua omista henkilökohtaisista tai ammatillisista kokemuksistaan tarinoiden kautta. On tärkeää, että osallistujat ymmärtävät, miten toiminta yhdistyy kurssin tavoitteisiin.

- Tarinankerrontavaiheessa opettaja on passiivinen tarkkailija, mutta voi samalla auttaa poimimaan tarinoista tärkeitä oivalluksia dokumentoimalla niitä esimerkiksi Padletalustalle tai valkotaululle.

\section{Kieleen ja kulttuuriin liittyviä huomioita:}

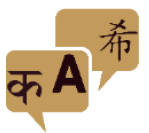

Osallistujien välisten suhteiden rakentaminen on erityisen tärkeää monikulttuurisessa ryhmässä. Vaikka tarinankerronta voi oikeanlaisissa olosuhteissa sujua luontevasti, tunne "ei-akateemisesta" työskentelystä voi rajoittaa opiskelijoita, mikäli he eivät ymmärrä tehtävän laajempaa merkitystä. Tarinaringit voivat tarjota uudenlaisia mahdollisuuksia hyödyntää eri kieliä. Onkin hyvä idea pohtia, miten tarinaringin olemusta voisi siirtää myös koko ryhmän oppimistilanteisiin, sillä se voi auttaa osallistujia liikkumaan eri kielten välillä. Tarinaringit voivat myös 
avata osallistujien silmiä ja mieliä havaitsemaan uudella tavalla ryhmän kulttuurista ja kokemuksellista moninaisuutta.

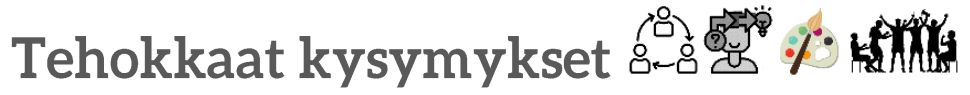

(Tehokkaiden) kysymysten laatiminen (engl. powerful questions) on menetelmä, jossa opiskelijat yhdessä muodostavat kysymyksiä käsitellystä aiheesta. Tehokkaat kysymykset voivat auttaa koko yhteisöä löytämään laajempia yhteyksiä ja merkityksiä jotakin tiettyä aihetta tarkasteltaessa. Tehokkaat kysymykset herättävät uteliaisuutta ja reflektoivaa keskustelua, ja niiden avulla voidaan tehdä näkyväksi perustavia taustaoletuksia ja luoda uusia ajattelun mahdollisuuksia. Kysymys on tehokas, kun sen rakenne, laajuus ja perustavat taustaoletukset muotoillaan niin, että se auttaa keskustelijoita fokusoimaan ja syventämään pohdintojaan ja rikastamaan siten koko yhteisön ajatteluprosessia.

\section{Vinkkejä opiskelijalle:}

- Tämän pedagogisen menetelmän avulla tähdätään kyselevään oppimiseen.

- Leikittele ja kokeile erilaisia kysymyssanoja (miten, miksi, mitä jos...) huomataksesi, miten ne laajentavat ja muuttavat keskustelun ulottuvuuksia.

- Kysymysten takana piilevien oletusten tarkastelu voi auttaa laajentamaan tietoisuutta niin omista kuin muiden opiskelijoiden tavoista ajatella. Kysymysten taka-ajatusten oivaltaminen voi auttaa kysymään jatkokysymyksiä ja siten osallistumaan entistä aktiivisemmin oppimisprosessiin.

\section{Vinkkejä opettajalle:}

- Taito esittää tehokkaita kysymyksiä on yksi askel kohti voimaannuttavaa oppimista, vaikka opiskelijat voivat alkuun kaivata apua ymmärtääkseen menetelmän merkityksen ja voiman.

- Tämä dialogisuuteen perustuva menetelmä voisi olla hyvä esitellä heti kurssin alussa, sillä sen avulla voidaan lisätä opiskelijoiden osallisuutta kurssin suunnittelussa. Se toimii hyvin myös uuden käsitteen esittelyn jälkeen, kun halutaan tutkia aihetta tarkemmin. Yhdessä laaditut kysymykset voivat lisätä opiskelijoiden osallisuuden kokemusta kurssilla.

\section{Kieleen ja kulttuuriin liittyviä huomioita:}

Tehokkaita kysymyksiä voidaan kysyä millä tahansa kielellä. Monikielisessä yhtei-

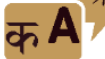
sössä osallistujat voivat vertailla eri kielisiin ilmauksiin liittyviä taustaoletuksia, kuten näyttäytyykö kasvatus luonnollisena vai kulttuurisena prosessina ja onko kehitys ja oppiminen sama asia. Osallistujat voivat laatia kysymyksiä eri kielillä huomatakseen, miten kysymykset toimivat eri kielillä ja erilaisissa kulttuurisissa konteksteissa. Akateemisessa maailmassa 
käytetään usein paljon aikaa kysymyksistä keskusteluun ja erilaisten ratkaisuvaihtoehtojen etsimiseen. Tehokkaiden kysymysten muotoilu yhdessä voi olla uudenlainen vuorovaikutuksellinen kokemus opiskelijoille.

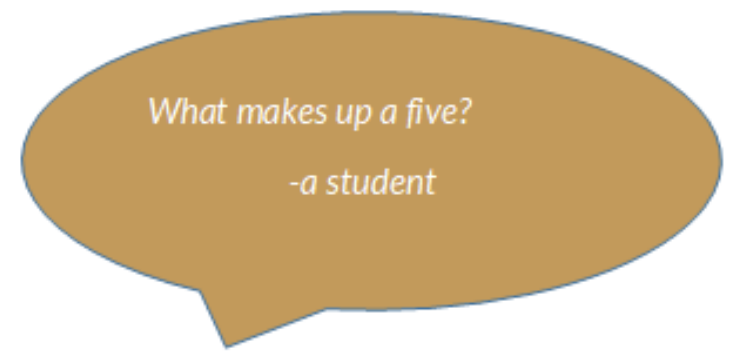

Tentit: yksilö-, ryhmä-, kirjallinen- ja suullinen tentti 1. 国貫:

Tentit ovat muodollinen tapa arvioida oppimista ja ne useimmiten päättävät opintojakson. Muiden opiskelumenetelmien tapaan myös tentit voidaan järjestää usealla eri tavalla, kuten suullisena tai kirjallisena, yksilö- tai ryhmätenttinä. Joskus tenttikysymykset voivat olla nähtävillä ennen varsinaista tenttiä, joskus taas tiedossa on vain tenttialue. https://help.jyu.fi/jp?id=kb_article\&sys_id=abb4f58adbc5a010d4306d34059619ec

\section{Vinkkejä opiskelijalle:}

- Varaa aikaa tenttiin valmistautumiselle, jotta et turhaan väsytä itseäsi juuri ennen tenttiä. Mikäli mahdollista, tutustu kurssin aiempien tenttien kysymyksiin ja suunnittele niihin vastauksia hyödyntämällä kurssin materiaaleja.

- Muista aina lukea tenttikysymykset ja vastausohjeet huolellisesti!

\section{Vinkkejä opettajalle:}

- Kuten muidenkin tehtävien kohdalla myös tenteissä on tärkeää, että opiskelijat ovat selvillä arviointikriteereistä.

Kieleen ja kulttuuriin liittyviä huomioita:

Tenttitilanteen muodollisuus voi jännittää opiskelijoita, mutta jännitystä voi helpottaa harjoittelemalla. Jos tentin muoto on opiskelijoille vieras, on reilua näyttää esimerkkikysymyksiä ja mallintaa, miten hyvä tenttivastaus rakennetaan. 


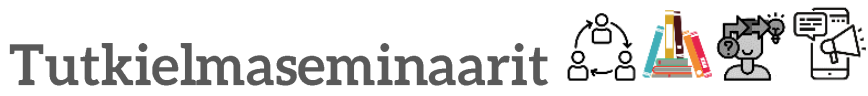

Tutkielmaseminaarien tarkoitus on tukea opiskelijoita omissa tutkielmaprosesseissaan. Tutkielmaseminaarit tarjoavat tilan, jossa opiskelijat voivat harjoitella esiintymistä, väittelyä ja tieteellisen käsityksen raportointia. Opiskelijat esittelevät seminaareissa omia tutkimuksiaan ja antavat toisilleen palautetta, sekä oppivat toistensa aiheista, kysymyksistä ja oivalluksista. Tutkielmaseminaarien avulla yhteisiä aiheita ja tutkielmaprosessia kokonaisuudessaan on helpompi lähestyä.

\section{Vinkkejä opiskelijalle:}

- Tutkielmaseminaari on hyvä tila pohdiskella tutkimuksen tekemistä yleisellä tasolla sekä tarkastella oman tutkimuksen toteuttamista (mitä, miksi ja miten).

- Tutkielmaseminaareissa työskennellään pienessä ryhmässä, ja ne rohkaisevatdialogiin muiden opiskelijoiden kanssa. Mitä enemmän osallistut keskusteluun, sitä enemmän saat hyötyä myös oman tutkielmasi tekemiseen.

\section{Vinkkejä opettajalle:}

- On hyvä varautua siihen, että opiskelijat voivat kommunikoida eri tavoin. On myös tärkeää arvostaa jokaisen opiskelijan erilaista taustaa ja valmistautumisen tasoa.

- Keskustelujen kannalta on hyvä, jos jokainen opiskelija jakaa omia kirjoituksia tai kysymyksiä muiden luettavaksi ennen seminaaritapaamista. Näin osallistujat voivat tutustua toistensa tutkimuksiin etukäteen ja valmistella kysymyksiä tai palautetta seminaaria varten.

\section{Kieleen ja kulttuuriin liittyviä huomioita:}

Tutkielmaseminaarit ovat arvokkaita kriittisen ajattelun ja akateemisten taitojen

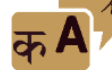
oppimistilanteita. On hyvä sallia erilaiset osallistumisen muodot ja tiedostaa kielen ja kulttuurin merkitys niin tutkimusprosessissa kuin seminaaritapaamisissa. Tutkielmaseminaarit tarjoavat myös mahdollisuuden harjoitella kansainvälisen tutkimustoiminnan käytäntöjä (esim. kaksikieliset esitykset, eri kielten merkityksen tunnistaminen tutkimuksen käsitteellistämisessä ja eri näkökulmien perusteleminen). Tutkielmaseminaarien keskusteluja voi rikastaa rohkaisemalla kollaboratiiviseen ja kriittiseen ajatteluun hyödyntämällä esim. infografiikkoja tai muita havainnollistavia keinoja.

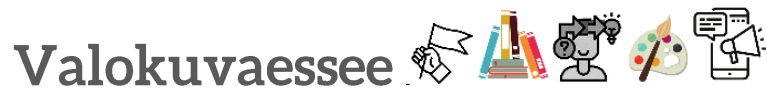

Valokuvaesseessä yhdistellään visuaalisia menetelmiä ja tekstiä, tavoitteena tuottaa temaattinen tarina. Kun teema on selvä, luodaan oma visuaalinen sanakirja ottamalla omia 
valokuvia tai hyödyntämällä kuvapankkeja, jotka tarjoavat ilmaisia CCO-lisenssillä varustettujakuvia (esim. https://unsplash.com/). Tekstin ja kuvien tulisi muodostaa yhtenäinen kokonaisuus, jolla on selkeä tavoite ja sanoma. Jokaisella kuvalla pyritään kiinnittämään lukijan huomio, johdattaen hänet tarinan teeman äärelle. Visuaalisuuden ja tekstin yhdistelmä voi olla hyvä keino sytyttää mielenkiintoa sekä provosoida ajattelemaan ja kyseenalaistamaan.

\section{Vinkkejä opiskelijalle:}

- Kannattaa valita vangitsevia, kerronnaltaan vahvoja kuvia, jotka välittävät haluamaasi viestiä.

- Kuvien tulisi ylläpitää yhteyttä esseen pääteemaan.

- Valitse kuvia sivustoilta, jotka laillisesti sallivat kuvien käytön opiskelutarkoitukseen. On myös tärkeää mainita kuvaaja dokumentissa.

\section{Vinkkejä opettajalle:}

- Valokuvaesseen ohjeistuksen rinnalla tulisi esitellä selkeä arviointikriteeristö, jotta opiskelijat ymmärtävät, millainen valokuvaesseen tulisi olla.

- Kokeile myös oman valokuvaesseen laatimista esimerkiksi omasta opetusfilosofiasta tai portfoliosta, jotta ymmärrät aktiviteetin haasteita ja mahdollisuuksia.

\section{Kieleen ja kulttuuriin liittyviä huomioita:}

Valokuvat ovat mainio työkalu monikulttuurisessa ryhmässä, sillä ne avaavat ikkunoita erilaisiin paikkoihin ja tilanteisiin ja auttavat eläytymään erilaisten ihmisten asemiin. Samalla ne tarjoavat paljon uusia näkökulmia. Visuaalisena elementtinä valokuvilla on oma kielensä, ja ne vähentävät varsinaisen tekstin tarvetta samalla kuitenkin laajentaen esseen ulottuvuuksia.

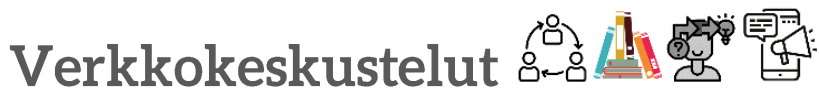

Verkkokeskustelut voivat sisältyä monenlaisiin kursseihin, ja niissä hyödynnetään useimmiten digitaalisia alustoja, jotka tarjoavat turvallisen ympäristön ideoiden vaihtamiselle. Verkkokeskustelut voivat olla aikataulutettuja tapahtumia, tai ne voivat olla ajallisesti joustavia. Opettaja voi joko antaa tilaa vapaamuotoiselle keskustelulle, tai asettaa minimilukumäärän, kuinka monta kertaa jokaisen opiskelijan tulee osallistua keskusteluun. Vaikka verkko-keskustelut tarjoavat ajallisesti ja tilallisesti vapaampia mahdollisuuksia vuorovaikutukseen, tulee niissä silti noudattaa akateemisen vuorovaikutuksen perussääntöjä: keskity siihen, mitä muut sanovat, yritä tarkastella asiaa eri näkökulmista, kysy kysymyksiä, valmistaudu perustelemaan omia kommenttejasi ja hyödynnä kurssimateriaalia argumenttien laatimisessa. 


\section{Vinkkejä opiskelijalle:}

- Verkkokeskustelun merkityksen ymmärtäminen auttaa sinua kehittämään omia osallistumisen tapojasi sekä muiden osallistumiseen (esim. kirjoituksiin ja kommentteihin) vastaamista.

- Ideaalitilanteessa online-keskustelut voivat provosoida ajattelemaan ja kehittää kyseenalaistamisen taitoja.

- Hyödynnä kurssin kirjallisuutta kehittääkseksi omia ideoitasi ja kirjoituksiasi. Muista kuitenkin, että on hyvän akateemisen käytännön mukaista viitata niihin lähteisiin, joita olet käyttänyt.

\section{Vinkkejä opettajalle:}

- Keskustelun tavoitteiden ja arviointikriteerien avaaminen (mikäli keskustelu arvioidaan) voitukea opiskelijoiden osallistumista.

- Verkkokeskustelut auttavat opiskelijoita syventymään kurssin akateemiseen sisältöön. Opiskelijat arvostavat usein sitä, että myös opettaja osallistuu keskusteluun jollakin tavalla, tapahtui se sitten palautteen tai johdattelevien kysymysten muodossa.

- Joskus opiskelijoiden kommenttien laatu merkitsee enemmän kuin kommenttien määrä.

\section{Kieleen ja kulttuuriin liittyviä huomioita:}

Verkkokeskustelut voivat tukea erityisesti kulttuurisesti moninaisia ryhmiä, sillä ne tarjoavat opiskelijoille joustavuutta ja aikaa työstää omia kommentteja ja vastauksia. Digitaalisille alustoille voidaan linkittää erilaisia online-kielityökaluja, kuten sanastoja ja sanakirjoja. Osallistujat voivat myös hyötyä mahdollisuudesta hyödyntää multimodaalisuutta omissa vastauksissaan (esim. piirtäen hahmoteltu idea, käsitekartta). Verkkokeskustelut voivat täydentää kasvokkain tapahtuvaa vuorovaikutusta. Molemmissa muodoissa on hyvä käydä läpi säännöt, jotka kannustavat ryhmää oikeudenmukaiseen toimintaan. Verkkokeskustelun aloituksissa tulisi aina käydä yksityiskohtaisesti läpi, miten live-keskustelu järjestetään (esimerkiksi aikaerot tulisi ottaa huomioon). Mikäli yhteydenpitoon tarvitaan audio-välineistöä, tulee äänen laatuun kiinnittää erityistä huomiota varmistamalla, että tila on rauhallinen, mikrofoni ja kaiuttimet (mieluiten kuulokkeet) toimivat ja että osallistumiseen tarvittava välineistö on itselle tuttua. Kurssin ohjeistukset ja vaatimukset tulee käydä läpi huolellisesti.

\section{Verkkokurssit 1 .}

Verkkokurssit suoritetaan useimmiten oppimisympäristössä (esim. Moodle), jossa opiskelijat näkevät kurssin ohjelman ja etenemisen, ja jossa he voivat kommunikoida muiden osallistujien kanssa. Verkkokurssilla voidaan myös hyödyntää yksinkertaisia verkkosivuja 
tai sähköpostiviestejä, joissa on linkit materiaaleihin ja tehtäviin sekä ohjeet tehtävien palautukseen (esim. palautetaanko tehtävä sähköpostilla vai palautuslaatikkoon). Monimuoto-opiskeluna toteutettavat kurssit voivat sisältää sekä kampuksella tapahtuvaa että online-toimintaa. Verkkokursseilla käytetään usein monipuolisesti erilaisia työkaluja ja menetelmiä, kuten videokokouksia, interaktiivisia ja yhteisöllisiä työtapoja sekä tehtäviä, jotka voivat sisältäälisätyn todellisuuden, tekoälyn yms. elementtejä. Enenevissä määrin verkkokursseilla hyödynnetään myös oppimisanalytiikkaa, jonka avulla tarkkaillaan ja tuetaan opiskelijaa kurssin eri vaiheissa. Verkkokurssit ja etäopiskelumahdollisuudet ovat jo pitkään olleet käytössä avoimissa yliopistoissa ja muissa erityisoppilaitoksissa, ja nyt myös perinteiset korkeakoulut tarjoavat online-kanavia hyödyntävää koulutusta.

\section{Vinkkejä opiskelijalle:}

- Vaikka et tapaisikaan opettajia ja kurssikavereita henkilökohtaisesti, kannattaa hyödyntää erilaisia menetelmiä, jotka mahdollistavat tavanomaista kommunikaatiota, kuten live-videot ja chat-foorumit. Näin opiskelusta voi tulla mukaansatempaavampaa ja yhteisöllisempää.

- Online-kurssit voivat sisältää itsenäistä työskentelyä ja ryhmätyötä, sekä erilaisia prosessin arvioinnin ja esittämisen keinoja, kuten itsenäisesti tai ryhmässä toteutettavia projekteja ja online-esitelmiä.

- Osa online-kursseista voi sisältää e-tentin tai tehtäväpaketin, mikä mahdollistaa suorituksen ajallista ja tilallista joustavuutta (esim. jatkuvasti käynnissä olevat MOOCit eli avoimet verkkokurssit).

- Mikäli sinulla on vaikeuksia päästä sisälle kurssin oppimisalustalle, materiaaleihin tai muihin työskentelytapoihin, ilmoita siitä kurssin opettajalle.

\section{Vinkkejä opettajalle:}

- Verkkokurssin ja -oppimisympäristön suunnittelu voi vaatia enemmän työtä kuin perinteisen kurssin suunnittelu.

- Opiskelijoilla voi olla hyvin erilaiset mahdollisuudet päästä hyvän tietokoneen ja nopean ja luotettavan internetin äärelle. Tämä on hyvä ottaa huomioon esimerkiksi kurssin aikataulussa ja tarvittaessa tarjota vaihtoehtoinen tapa suorittaa kurssi.

- Myös verkkokurssit vaativat vuorovaikutusta, ohjeistusta ja palautetta. Live-vuorovaikutus, keskustelufoorumit ja chat-toiminnot voivat auttaa opiskelijoita osallistumaan sisältöjen ja oppimisen kannalta arvokkaisiin keskusteluihin.

- Selkeä ja yksiselitteinen arviointikriteeristö on erityisen tärkeä, mikäli kurssi ei sisällä live- tai online-tapaamisia. Arvioinnissa voidaan hyödyntää monipuolisesti erilaisia, oppimista demonstroivia keinoja. On myös hyvä idea pitää yllä avoimia foorumeja, joilla opiskelijat voivat anonyymisti tai yksityisviesteillä pyytää tarkennuksia ja lisäohjeita. 


\section{Kieleen ja kulttuuriin liittyviä huomioita:}

Kansainväliset verkkokurssit tarjoavat mahdollisuuksia oppia ja hyödyntää eri kieliä. Riippuen kurssin suunnitelmasta ja tavoitteista ryhmien muodostaminen se-

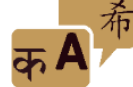
koittamalla erilaisista kulttuurisista ja kielellisistä taustoista tulevia opiskelijoita voi olla jopa helpompaa kuin perinteisillä kursseilla. Virtuaalisuus tarjoaa mahdollisuuksia, jotka voivat laajentaa kokemuksia erilaisista koulutuksellisista ympäristöistä, kulttuureista ja asiantuntijuudesta turvallisella ja kestävällä tavalla. Kurssin järjestäjän tulisikin ottaa huomioon mahdolliset eroavaisuudet osallistujaryhmien taustoissa ja työskentelytavoissa, mukaan lukien odotukset ja ajatukset laadukkaasta koulutuksesta.

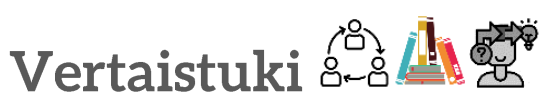

Vertaistuki on akateemisen toiminnan muoto, jossa hyödynnetään yhteistyötaitoja ja kehitetään samalla yhteistä tietoa ja ymmärrystä. Vahva vertaistuki auttaa rakentamaan yhteisöllisyyttä opiskelijoiden kesken, ja vaikuttaa siten positiivisella tavalla oppimisympäristöön. Vertaistukea voidaan harjoitella monin eri tavoin, kuten työskentelemällä pareittain, kokoamalla yhteisiä miellekarttoja, kokeilemalla erilaisia rooleja ryhmässä työskenneltäessä, arvostamalla moninaisia ideoita ja tarjoamalla rakentavaa palautetta. Vertaistuki voi olla osa yksittäisen kurssin suoritusta, mutta sitä voidaan vaalia myös osana laajempaa akateemista kulttuuria.

\section{Vinkkejä opiskelijalle:}

- Reflektion ja kriittisen ajattelun kautta heränneiden kysymysten esittäminen on tärkeä osa vertaistukea ja akateemista vuorovaikutusta.

- Pyri olemaan aktiivinen kuuntelija- se että löytää yhteyksiä esitettyjen asioiden väliltä rikastuttaa kaikkien osapuolten oppimista. Yhteistyön ja ryhmätyössä koettujen vahvuuksien ja heikkouksien reflektointi kehittää vertaistuen taitoja ja edistää ilmapiiriä, jossa on helppo antaa rakentavaa palautetta.

\section{Vinkkejä opettajalle:}

- Kannattaa sisällyttää yhteistyötä sisältäviä työtapoja opetussuunnitelmaan, koska se rohkaisee opiskelijoita vuorovaikutukseen, joka tukee oppimista ja yhteisen ymmärryksen kehittymistä.

- Lähestymistavat, jotka kannustavat reflektioon ja itsetietoisuuteen, auttavat kehittämään vertaistuesta positiivista akateemisen opiskelun piirrettä. Ryhmätyö, olipa se sitten pieni tai suuria, on usein toivottu, vertaistukea rakentava toimintatapa. 


\section{Kieleen ja kulttuuriin liittyviä huomioita:}

Kieleen liittyvät erot ja kulttuuriset kokemukset voivat vaikuttaa merkittävästi siihen, miten opiskelijat suhtautuvat vertaistukeen. Erilaisten vertaistuen mahdollisuuksien tunnistaminen ja jokaisen osallistujan panoksen arvostaminen voivat auttaa opiskelijoita työskentelemään ja rakentamaan ymmärrystä yhdessä. Yhteistyötä vaativien menetelmien käyttäminen on tärkeä osa vertaistuen kehittymistä kulttuurisesti moninaisessa oppimisympäristössä.

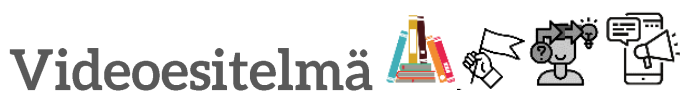

Videoesitelmällä luodaan digitaalinen yhteys esitelmän pitäjän ja esiteltävän aiheen välille. Tämä yhteys luodaan yhdistelemällä hyvää käsikirjoitusta, kiinnostavaa ääntä ja hyvin ajoitettuja, dynaamisia visuaalisia elementtejä.

\section{Vinkkejä opiskelijalle:}

- Pyri ajattelemaan videota kokonaisuutena ja löytämään yhtenäinen malli, joka yhdistää videon moninaisen sisällön kuten haastattelut, kerronta ja havainnollistukset.

- Pohdi kysymystä "Mikä on videoesitelmäni pääasiallinen tarkoitus?" ja jaa sisältö loogisiksi osiksi.

- Esityksen käsikirjoittaminen ja harjoitteleminen auttavat suunnittelemaan esityksestä tehokkaan.

- Kun valitset visuaalisia elementtejä, lähde tekstien tai PowerPoint -esityksen sijaan pohtimaan, millainen kuvitus voisi tukea aihetta.

\section{Vinkkejä opettajalle:}

- Opiskelijoita on hyvä rohkaista laatimaan lista käyttämistään lähteistä (tai esittämistään kuvista/diagrammeista) akateemiseen tyyliin.

- Muistuta opiskelijoita valitsemaan kuvia, joilla on tarkoituksenmukainen käyttöoikeus.

- Jos yliopistolla on tarjota tiloja tai välineitä videoiden tekemiseen ja opiskelijat työstävät videota yliopisto-opiskelua varten, kannattaa opiskelijoita ohjata hyödyntämään yliopiston käytössä olevaa välineistöä.

\section{Kieleen ja kulttuuriin liittyviä huomioita:}

Videoesitelmät ovat kielellisesti joustavia, sillä niihin voi lisätä tekstityksiä eri kielillä. Esityksen voi myös pitää omalla äidinkielellä, ja liittää videoon yhteisen työskentelykielen tekstitykset. Tehokkaat visuaaliset elementit ja havainnollistukset tarjoavat mahdollisuuksia monikielisille videoesitelmille. 


\section{Videoluento 1}

Videoluennot pidetään tai ne ovat saatavilla kurssin verkkoympäristössä. Videoluennot mahdollistavat joustavaa työskentelyä niin opettajille kuin opiskelijoille.

\section{Vinkkejä opiskelijalle:}

- Videoluennot ovat useimmiten yksi osa verkkokurssia, ja ne ovat käteviä työkaluja omaan tahtiin opiskeltaessa. Niitä kannattaa katsoa uudelleen, mikäli se auttaa ymmärtämään sisältöä paremmin.

- Videoluentoja katsoessa kannattaa tehdä muistiinpanoja luennon tärkeimmistä asioista. Myös omat ajatukset sekä mahdolliset kysymykset kannattaa kirjoittaa muistiin.

- Mikäli videoluennolla on tehtäviä, joiden avulla siirrytään seuraavaan aiheeseen, kannattaa video pysäyttää ja käyttää aikaa tehtävän tekemiseen.

\section{Vinkkejä opettajalle:}

- Videoluennossa kannattaa hyödyntää erilaisia apuvälineitä ja toimintamalleja, jotta luento olisi mukaansatempaava ja interaktiivinen, ja tukisi aktiivista oppimista. Interaktiivisuutta voi lisätä esimerkiksi videoiden välillä pohdittavien kysymysten tai tehtävien avulla.

- Luennon rakenne on hyvä käydä läpi esityksen alussa, ja loppuun on hyvä tehdä yhteenveto.

- Videoluentoa kootessa on helpompi etsiä jo olemassa olevia, aiheeseen liittyviä videoita ja tehdä itse niitä täydentäviä videopätkiä, kuin rakentaa alusta asti kokonaan uusi video.

- Eräiden ohjelmistojen avulla näytön voi jakaa niin, että samanaikaisesti näkyvillä on luennoitsijan lisäksi myös esitys, kaavio tai piirros. Tämä auttaa katsojaa pitämään huomionsa esityksen sisällössä.

\section{Kieleen ja kulttuuriin liittyviä huomioita:}

Videoluentoja voidaan tehdä eri kielillä, ja niihin voi lisätä tekstitykset. Videoilla

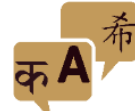
voisi olla myös teemaan liittyviä kuvia erilaisista kulttuurisista konteksteista, mikä laajentaisi luennon näkökulmaa. Tällä hetkellä JYU:Ila on käytössä helppokäyttöinen työkalu, jonka avulla videoihin voi lisätä tekstityksiä. Opiskelijat voisivat myös hyötyä siitä, että he saisivat tutustua luennon materiaaleihin luennon aikana. 


\section{Visuaalinen sadonkorjuu (kuvakiteytys, visualisointi)}

"Visuaalinen sadonkorjuu" (Visual harvesting) on tiedon prosessoinnin ja säilömisen menetelmä, joka hyödyntää visuaalisuutta yhdessä tekstin kanssa. Visuaalinen sadonkorjuu on luova prosessi, jossa tavoitteena on löytää yhteisen ajatteluprosessin oleellisin ydin. Visuaaliseen esitykseen kootaan näkyviin ideat ja kaikki se oleellinen informaatio, josta on puhuttu yhteisissä tapaamisissa. Visuaalinen sadonkorjuu edesauttaa ryhmän oppimista ja kulttuurisen muistin kehitystä. Kun luodaan merkityksiltään laajoja kuvia, joissa integroituvat sisällöt, täsmälliset oivallukset ja päätöksentekoa auttavat asiat, hyödynnetään ryhmän yhteisöllistä tietoa ja rakennetaan samalla mahdollista synergiahyötyä (ryhmä on enemmän kuin yksilö).

\section{Vinkkejä opiskelijalle:}

- Yhdistelemällä luovasti visuaalisia keinoja ja tekstiä saadaan tehokkaasti esiin ryhmän keskusteluissa esiin tulleita merkityksiä koko kurssin ajalta. Visuaalinen malli voi myös sisältää kysymyksiä ja harmaita, epäselviä alueita, joihin tutustumista voidaan jatkaa. Tämä on oleellinen osa visuaalista järkeistämistä ja selkeyttämistä.

\section{Vinkkejä opettajalle:}

- Tämä prosessi sisältää perinteistä ajatuskarttaa (tai visuaalista karttaa) enemmän aitoa ja syvää kuuntelua, sillä tavoitteena on löytää se ydin, mikä löytyy kuultujen sanojen ja luetun tekstin takaa.

- Koottu visuaalinen malli toimii myös jatkossa tutkivan oppimisen ja tehokkaiden kysymysten ohjaamien ryhmäkeskustelujen työvälineenä. Yhtä lailla se voi toimia arvioinnin, oppimisen tai reflektion välineenä.

\section{Kieleen ja kulttuuriin liittyviä huomioita:}

Visuaalisessa sadonkorjuussa korvataan akateemiseen kielenkäyttöön liittyvä paine, ja keskitytään avainsanojen ja laajojen ylä- ja alakäsitteiden korostamiseen yhdistelemällä tekstiä ja visuaalisia keinoja. Visualisoinnilla on aivan omanlaisensa kieli, joka on uniikki niin yksittäiselle oppijalle kuin ryhmälle. Kulttuurisiin eroihin visuaalisten mallien tulkinnassa on hyvä kiinnittää huomiota visuaalisen mallin täytyy olla käsitettä/käsitystä edustaessaan riittävän kattava. 


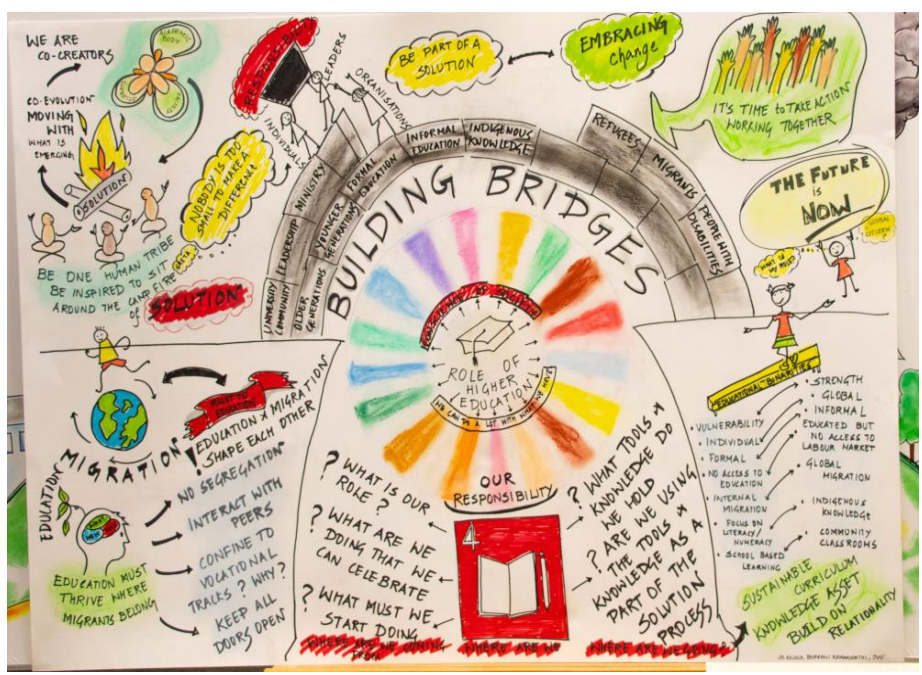

Kuva 4. Visuaalinen sadonkorjuu JYU SDG4 2019 seminarista (CBhavani Ramamoorthi

\section{Visuaaliset menetelmät ja työkalut}

Visuaaliset menetelmät ulottuvat kirjoitetun ja puhutun kielen taakse, kun niiden avulla tarkastellaan ja esitetään ideoita ja ymmärrystä. Visuaaliset menetelmät ovat enemmän kuin informaatiokatsauksia, vaikkakin nämä voivat toimia osana visuaalista esitystä, kun niihin lisätään myös omia huomioita, kuvitusta ja korostuksia. Visuaalisia työkaluja on monenlaisia: postereita, infografiikoita, luovia esitelmiä, kuvatietokantoja, simuloivia ympäristöjä ja yhteistyöhön soveltuvia videotyökaluja. Erilaiset sanapilvet, Canva.com ja Powtoons ovat hyödyllisiä online-työkaluja.

\section{Vinkkejä opiskelijalle:}

- Visuaalisten menetelmien avulla voit esittää ideoitasi, eri ylä- ja alakäsitteiden ja teemojen välisiä suhteita (miellekartat, käsitekartat) ja seurata etenemistäsi kohti oppimistavoitteitasi.

- Visuaalisten työkalujen avulla voit myös kehittää ongelmanratkaisu- ja kriittisen ajattelun taitojasi.

- Visuaalisten työkalujen avulla voit korostaa tehtävässäsi tai esseessäsi ilmenevää ajattelua, ja siten tehdä tekstistä lukijalle selkeämpää ja yhtenäisempää.

\section{Vinkkejä opettajalle:}

- On hyvä opetella käyttämään erilaisia visuaalisia menetelmiä. Visuaalisiin menetelmiin ja työkaluihin tutustuessa kannattaa myös hyödyntää opiskelijoiden tietämystä. 
- Luentotilanteissa visuaalisia työkaluja voidaan hyödyntää tehokkaasti luennon runkona, ja samalla tukea visuaalisia oppijoita, joille pelkän auditiivisen informaation ja ohjeistuksen varassa toimiminen on haastavaa.

Kieleen ja kulttuuriin liittyviä huomioita:

Yksinkertaisten visuaalisten menetelmien hyödyntäminen monikulttuurisessa ryhmässä voi auttaa jäsentämään informaatiota ja hahmottamaan eri käsitteiden välisiä yhteyksiä.. Visuaalisuus on hyvä keino korvata suuri, usealle opiskelijalle haastavalla tai kokonaan vieraalla kielellä kirjoitettu tekstimäärä. Myös opiskelijat voivat laatia visuaalisia karttoja omalla kielellään, ja siten harjaannuttaa kriittistä ajattelua sekä ymmärrystä eri käsitteiden välisistä monimutkaisista suhteista. Visuaalisia malleja voidaan esittää eri kielillä lisäämällä niihin ymmärrystä tukevaa tekstiä.

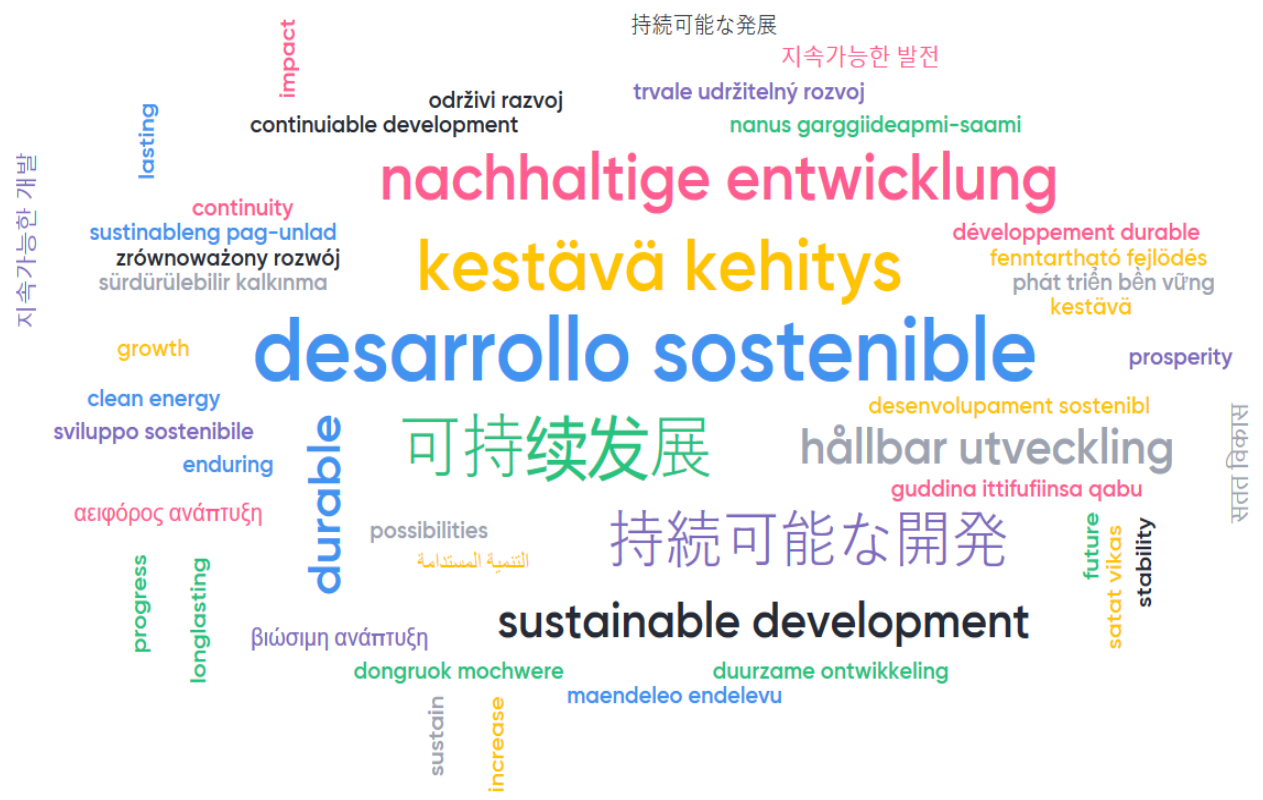

Kuva 5. Esimerkki sanapilvestä, joka on luotu verkkosivulla www.mentimeter.com

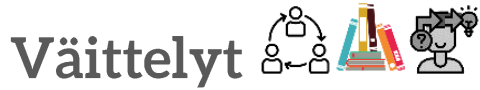

Väittelyt ovat yleisön edessä tapahtuvia, järjestettyjä keskusteluja, joissa tuodaan yhteen tiettyä aihetta koskevia, vastakkaisia näkemyksiä. Väittelyyn osallistujien tulee esittää annetussa ajassa argumentteja, jotka tukevat heidän kantaansa. Väittelyjen avulla on mahdollista avata laajempaa ja moniäänisempää keskustelua, koska se tuo esiin erilaisia argumentteja ja näkökulmia, joita tarkastellaan kriittisesti. Väittelyn puheenjohtaja esittelee 
väittelijät ja vastaa väittelyn etenemisestä. Väittelyt sisältävät tiimityötä ja nopeaa ajattelua sekä yksityiskohtaisen jälkianalyysin, jossa keskustellaan väittelyn etenemisestä varsinaisen väittelyn jälkeen.

\section{Vinkkejä opiskelijalle:}

- Väittelyt auttavat laajentamaan ajattelua, käsittämään erilaisia näkökulmia ja tiedostamaan erilaisten näkemysten olemassaoloa.

- Argumenttien täytyy olla sisällöiltään loogisia. Niiden täytyy olla selkeitä, hyväksyttäviä ja uskottavia, ja niistä täytyy löytyä arkielämän esimerkkejä ja selityksiä. Hyvään väittelyetikettiin kuuluu, että jokainen väittelijä pyrkii linkittämään esittämiään puheenvuoroja ja pääpointteja jo esitettyihin, jolloin väittely pysyy johdonmukaisena.

- Väittelijän tulee rytmittää oma puheenvuoronsa käytettävän ajan mukaan. Puheenvuorossa tulee keskittyä puhujan omaa kantaa tukevan sisällön sekä argumenttien ja vastaargumenttien esittämiseen. Puheenvuorossa tulee olla myös selkeä rakenne ja siitä tulee käydä ilmi puheenvuoron tarkoitus. Näin puheenvuoroa on helpompi seurata ja siitä tulee paljon vaikuttavampi.

\section{Vinkkejä opettajalle:}

- On hyvä varautua siihen, että opiskelijoilla voi olla hyvin erilaisia kokemuksia väittelyistä ja väittelemisestä, mikä voi vaikuttaa osallistumisvalmiuksiin. Tästä syystä osallistumisen kannattaa ainakin alkuvaiheessa olla vapaaehtoista.

- Argumentaatiossa esiintyminen ja kieli ovat tärkeässä asemassa. Koska kaikilla osallistujilla ei välttämättä ole samanlaisia puhetaitoja tai itseluottamusta, kannattaa opiskelijoille painottaa valmistautumisen merkitystä.

- Väittelyn rakenne ja ohjeistus on hyvä käydä opiskelijoiden kanssa tarkasti läpi. Näin väittelystä tulee tehokas ja siihen on helpompi osallistua.

\section{Kieleen ja kulttuuriin liittyviä huomioita:}

Väittelyt ovat tärkeä osa demokraattista yhteiskuntaa, ja ne voivat olla merkittävässä roolissa kulttuurien välisessä dialogissa. Osallistujien kielitaidoissa esiintyvät suuret erot voivat aiheuttaa merkittäviä hankaluuksia ja luoda esimerkiksi epätasaisia valta-asetelmia. Valmistautuminen roolileikkien, puheiden sekä mahdollisten kysymysten avulla voi kuitenkin auttaa pärjäämään myös varsinaisessa väittelyssä. Väittelyn aikana puheenjohtaja voi myös avustaa keskustelua pyytämällä kysymykset kirjallisena digitaalisille alustoille (esim. Padletille) ja antamalla väittelijöille aikaa valmistella vastauksiaan. Koska väittelyn tavoitteena on ratkaisun löytämisen ohella kehittää julkisen puhumisen taitoja, on jälkikäteen tärkeää pohtia, mitä väittelykokemuksessa opittiin ja mihin voitaisiin jatkossa kiinnittää huomiota. 


\section{Yksilö- ja ryhmänohjaus 1}

HOPS-kurssit, opetusharjoittelun tapaamiset ja tutkielmaseminaarit ovat esimerkkejä ohjauksen eri muodoista. Ohjaus voi olla yksilö- tai ryhmäkohtaista. Ohjauksessa keskitytään enemmän oppimisprosessiin kuin sisältöön, ja sen pitäisi auttaa opiskelijaa etenemään kohti tavoitteita. Tärkeä osa ohjausta on, että opiskelijoille tarjotaan tilaa jakaa omia kokemuksiaan työskentelystä suhteessa annettuihin tehtäviin tai kokonaisuuksiin.

\section{Vinkkejä opiskelijalle:}

- Ohjaus on sitä hyödyllisempää, mitä enemmän jaat kohtaamiasi haasteita ja kysymyksiä. Muista, että ohjauksen tavoitteena on auttaa sinua omissa opinnoissasi.

- Ohjaustapaamisiin on tärkeää valmistautua esimerkiksi lukemalla kirjallisuutta ja lähettämällä omia tekstejä annetussa aikataulussa. Jälkikäteen kannattaa pohtia, mitä tapaamisessa puhuttiin ja sovittiin.

\section{Vinkkejä opettajalle:}

- Ohjaustilanteeseen on hyvä suhtautua tärkeänä oppimistilanteena, jossa tuttuja asioita on mahdollista tarkastella opiskelijan perspektiivistä.

- Ohjauksen tulisi auttaa opiskelijaa eteenpäin, mutta myös auttaa tiedostamaan niitä esteitä, jotka voivat haitata työskentelyn etenemistä.

\section{Kieleen ja kulttuuriin liittyviä huomioita:}

Opiskelijoilla voi olla hyvin erilaisia kokemuksia ja odotuksia ohjaukselle. Osa saattaa odottaa tarkkoja toimintaohjeita, ja kokea siksi suomalaisen yliopistoelä-

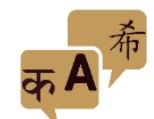
män vapauden hämmentävänä, kun taas osa voi kokea vapauden hyvinkin virkistävänä. Ohjaussuhteen alussa on hyvä käydä yhdessä tarkasti läpi, mitä ohjausprosessiin kuuluu ja mitä siltä tulee odottaa.

\section{Zine-muotoiset esitykset}

Zine on epämuodollinen ja luova, pienimuotoisille visuaalisille esityksille sopiva formaatti. Zine-muotoisessa esityksessä voidaan hyödyntää sanoja ja kuvia (piirrettyjä, valokuvia, leikattuja) ideoiden ja teemojen tarkastelussa sekä kokemusten raportoinnissa ja jakamisessa. Zinen visuaalinen, rakenneltu luonne rohkaisee opiskelijaa (tekijää) pohtimaan huolellisesti työn avulla avautuvaa narratiivia sekä sen taustalla vaikuttavia taustatekijöitä. Koska zine on avoin formaatti, sitä voidaan käyttää usealla eri tavalla. Alla olevista 
linkeistä voit katsoa, miten zine-muotoisia esityksiä voidaan tehdä - vaikkakin sisältö riippuu aina tehtävänannosta ja zinen tarkoituksesta! https://www.wikihow.com/Make-a-Zine https://www.youtube.com/watch?v=9INUang4oMA

\section{Vinkkejä opiskelijalle:}

- Zinen kokoaminen antaa mahdollisuuksia tarkastella aihetta erilaisista näkökulmista ja lisätä siihen uudenlaisia ulottuvuuksia. Hyödynnä siis rohkeasti luovuuttasi sekä moninaisia, visuaalisia ja kielellisiä resurssejasi!

\section{Vinkkejä opettajalle:}

- Zinen kokoaminen antaa opiskelijoille mahdollisuuden hyödyntää luovia resurssejaan ja ilmaista epätavanomaisiakin ideoita. Tällaisten luovien formaattien merkitys opiskelulle on hyvä avata sanallisesti.

Kieleen ja kulttuuriin liittyviä huomioita:

Vastakulttuuriin kuuluvina ilmaisun muotoina zinet tarjoavat tilaa tutkia erilaisia

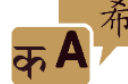
näkökulmia ilman perinteisiä, akateemisia rajoitteita. Tällainen luova formaatti voi antaa hyvän mahdollisuuden käsitellä sensitiivisiä aiheita, kuten identiteetin kehittymistä, suhdetta paikkaan ja tukea ymmärryksen kehittymistä. 


\section{SANASTO}

\begin{tabular}{|c|c|c|}
\hline $\begin{array}{l}\text { Akateemisten lähteiden valitsemi- } \\
\text { nen ja niihin viittaaminen }\end{array}$ & $\begin{array}{l}\text { Reading assign- } \\
\text { ments }\end{array}$ & 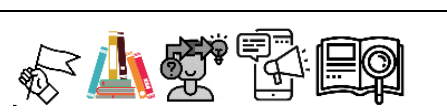 \\
\hline Demot (demonstraatiot) & $\begin{array}{l}\text { Demos (Demonstra- } \\
\text { tions) }\end{array}$ & 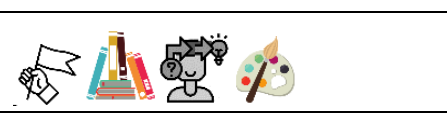 \\
\hline $\begin{array}{l}\text { Digitaaliset oppimisympäristöt ja } \\
\text { alustat }\end{array}$ & $\begin{array}{l}\text { Digital learning envi- } \\
\text { ronments and plat- } \\
\text { forms }\end{array}$ & ים \\
\hline Draama & Drama & 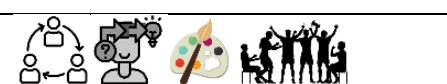 \\
\hline Etäopiskelu & Distance learning & \\
\hline $\begin{array}{l}\text { Gallery walk (näyttelykävely, gal- } \\
\text { leriakävely) }\end{array}$ & Gallery walk & (19) \\
\hline Infografiikat (tai infogrammit) & Infographics & \\
\hline $\begin{array}{l}\text { Integroivat opiskelumuodot/ } \\
\text { opiskelutekniikat }\end{array}$ & $\begin{array}{l}\text { Integrative modes of } \\
\text { study }\end{array}$ & \\
\hline Itsenäinen opiskelu & $\begin{array}{l}\text { Independent learn- } \\
\text { ing }\end{array}$ & \\
\hline Itsenäiset oppimistehtävät & $\begin{array}{l}\text { Independent tasks } \\
\text { and activities }\end{array}$ & \\
\hline Kenttätyö & Fieldwork & 이료 \\
\hline $\begin{array}{l}\text { Keskustelukartta tai hiljainen di- } \\
\text { alogi }\end{array}$ & $\begin{array}{l}\text { Conversation map- } \\
\text { ping or silent dia- } \\
\text { logue }\end{array}$ & 8 \\
\hline Kirjatentti/eTentti & Book exam/eExam & \\
\hline Kirjoittamisen strategiat & $\begin{array}{l}\text { Prewriting strate- } \\
\text { gies }\end{array}$ & 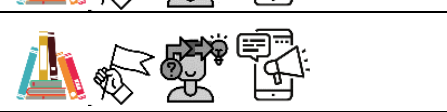 \\
\hline Kirjoitustehtävä/essee & $\begin{array}{l}\text { Written assignment } \\
\text { / essay }\end{array}$ & 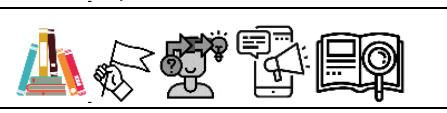 \\
\hline Kommentoitu kirjallisuusluettelo & $\begin{array}{l}\text { Annotated bibliog- } \\
\text { raphy }\end{array}$ & 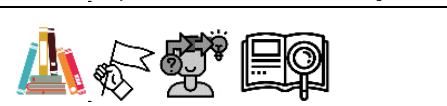 \\
\hline Kriittinen ajattelu & Critical thinking & (ㅁㅇ \\
\hline $\begin{array}{l}\text { Learning café ja pedagoginen kah- } \\
\text { vila }\end{array}$ & $\begin{array}{l}\text { Learning café and } \\
\text { pedagogical cafe }\end{array}$ & 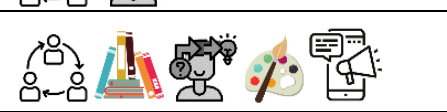 \\
\hline Luennot & Lectures & 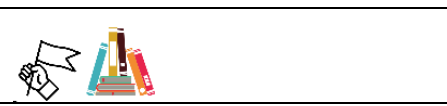 \\
\hline Luentopäiväkirja & $\begin{array}{l}\text { Lecture diary / } \\
\text { learning log }\end{array}$ & 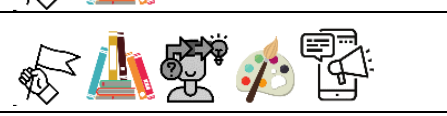 \\
\hline
\end{tabular}




\begin{tabular}{|c|c|c|}
\hline Lukemistehtävät & $\begin{array}{l}\text { Reading assign- } \\
\text { ments }\end{array}$ & 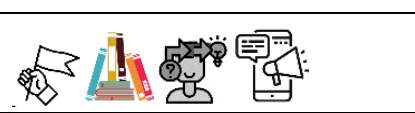 \\
\hline Luova kirjoittaminen & Creative writing & 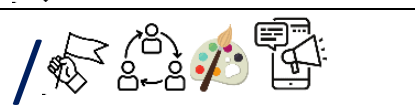 \\
\hline Muistiinpanojen tekeminen & $\begin{array}{l}\text { Note-making / note- } \\
\text { taking }\end{array}$ & 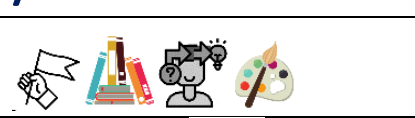 \\
\hline Opetus/Kontaktiopetus & Classes & 13 \\
\hline Oppimispäiväkirja & Learning diary & 1id \\
\hline $\begin{array}{l}\text { Oppimistehtävät: oppimispäiväkir- } \\
\text { jat, esseet, lukemistehtävät, ryh- } \\
\text { mätyöt }\end{array}$ & $\begin{array}{l}\text { Assignments: learn- } \\
\text { ing journals, essays, } \\
\text { reading tasks, group } \\
\text { presentations }\end{array}$ & 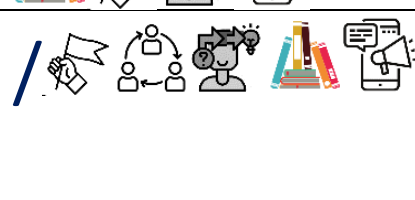 \\
\hline Osallistuminen & Participation & A 1 \\
\hline Palaute (vertais- tai ryhmäpalaute) & $\begin{array}{l}\text { Feedback (peer, } \\
\text { group) }\end{array}$ & 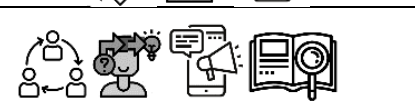 \\
\hline Posteriesitykset & $\begin{array}{l}\text { Poster presenta- } \\
\text { tions }\end{array}$ & 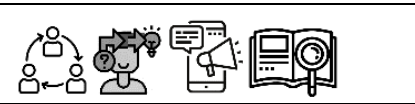 \\
\hline Projektioppiminen & $\begin{array}{l}\text { Project-based learn- } \\
\text { ing }\end{array}$ & 保 \\
\hline $\begin{array}{l}\text { Reflektiiviset luonnosvihkot (ks. } \\
\text { myös osat Reflektio ja Visuaaliset } \\
\text { työkalut) }\end{array}$ & $\begin{array}{l}\text { Reflective sketch- } \\
\text { book }\end{array}$ & i. \\
\hline Reflektio & Reflection & 10 \\
\hline Ryhmätyönä toteutettava esitelmä & Group presentations & 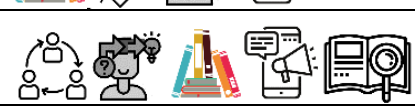 \\
\hline Ryhmätyöskentely & Group work & 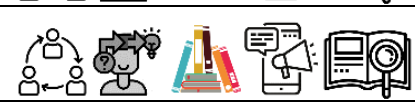 \\
\hline Tarinarinki & Story circles & 㔯 \\
\hline Tehokkaat kysymykset & $\begin{array}{l}\text { Designing powerful } \\
\text { questions }\end{array}$ & 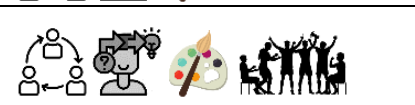 \\
\hline $\begin{array}{l}\text { Tentit: yksilö-, ryhmä-, kirjallinen- } \\
\text { ja suullinen tentti }\end{array}$ & $\begin{array}{l}\text { Examinations: indi- } \\
\text { vidual, written, } \\
\text { group oral exam }\end{array}$ & 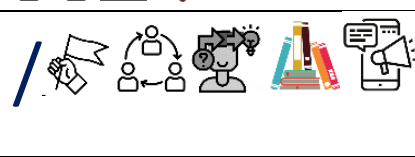 \\
\hline Tutkielmaseminaarit & Research seminars & 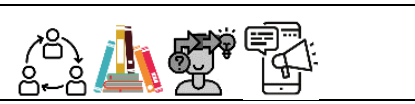 \\
\hline Valokuvaessee & Photo essay & 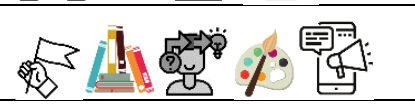 \\
\hline Verkkokeskustelut & Online discussion & 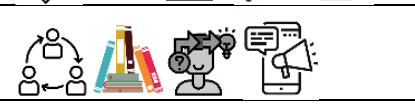 \\
\hline Verkkokurssit & Online courses & 11 \\
\hline
\end{tabular}




\begin{tabular}{|c|c|c|}
\hline Vertaistuki & Peer support & rô \\
\hline Videoesitelmä & Video lecture & 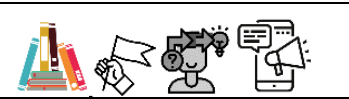 \\
\hline Videoluento & Video presentation & 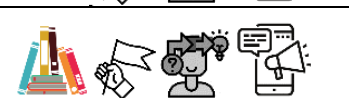 \\
\hline $\begin{array}{l}\text { Visuaalinen sadonkorjuu (kuvakit- } \\
\text { eytys, visualisointi) }\end{array}$ & Visual harvesting & 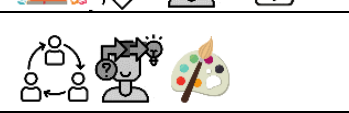 \\
\hline Visuaaliset menetelmät ja työkalut & $\begin{array}{l}\text { Visual methods and } \\
\text { tools }\end{array}$ & 晠资 \\
\hline Väittelyt & Debates & ro. \\
\hline Yksilö- ja ryhmänohjaus & $\begin{array}{l}\text { Supervision: individ- } \\
\text { ual or group }\end{array}$ & 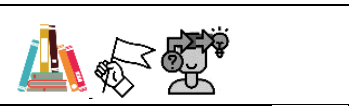 \\
\hline Zine-muotoiset esitykset & Zines & $/$ 得 $\%$ 国 \\
\hline
\end{tabular}

